\title{
Honeywell
}

\section{Feasibility Study - Using a Solar Evaporator to Reduce the Metalworking Fluid (MWF) Waste Stream}

Federal Manufacturing \& Technologies

L. J. Lazarus

KCP-613-8522

Published September 2008

Final Report

Approved for public release; distribution is unlimited.

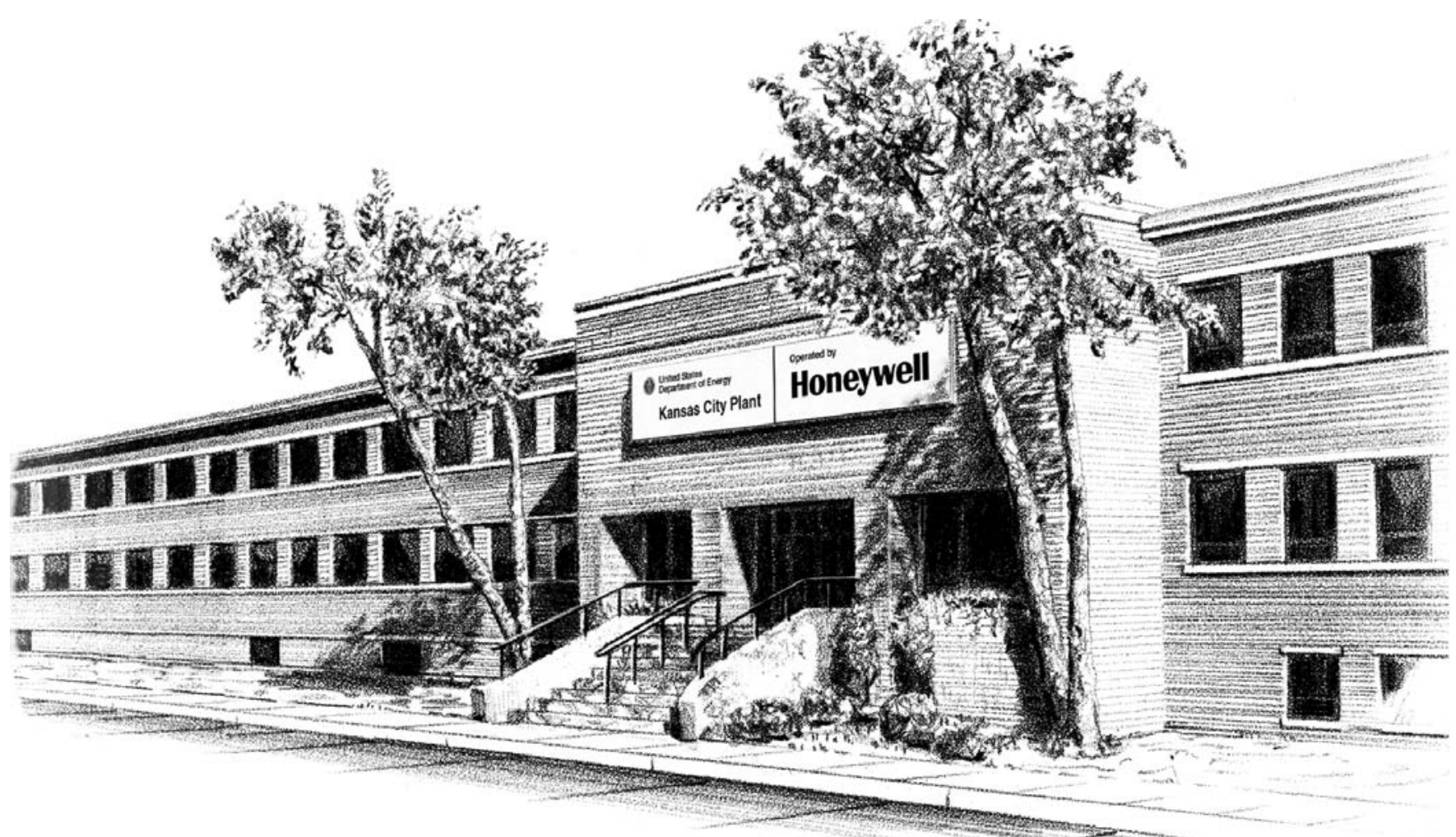

Prepared under prime contract DE-ACO4-01AL66850 for the

United States Department of Energy 


\section{DISCLAIMER}

This report was prepared as an account of work sponsored by an agency of the United States Government. Neither the United States Government nor any agency thereof, nor any of their employees, makes any warranty, express or implied, or assumes any legal liability or responsibility for the accuracy, completeness, or usefulness of any information, apparatus, product, or process disclosed, or represents that its use would not infringe privately owned rights. Reference herein to any specific commercial product, process or service by trade names, trademark, manufacturer, or otherwise, does not necessarily constitute or imply its endorsement, recommendation or favoring by the United States Government or any agency thereof. The views and opinions of authors expressed herein do not necessarily state or reflect those of the United States Government or any agency thereof.

All data prepared, analyzed and presented has been developed in a specific context of work and was prepared for internal evaluation and use pursuant to that work authorized under the reference contract. Reference herein to any specific commercial product, process or service by trade name, trademark, manufacturer, or otherwise, does not necessarily constitute or imply its endorsement, recommendation or favoring by the United States Government, any agency thereof or Honeywell Federal Manufacturing \& Technologies, LLC.

Printed in the United States of America.

This report has been reproduced from the best available copy.

Available to DOE and DOE contractors from the Office of Scientific and Technical Information, P.O. Box 62, Oak Ridge, Tennessee 37831; prices available from (865) 576-8401, FTS 626-8401.

Available to the public from the National Technical Information Service, U.S. Department of Commerce, 5285 Port Royal, Rd., Springfield, Virginia 22161, (703) 487-4650.

A prime contractor with the United States Department of Energy under Contract Number DE-AC04-O1AL66850
Honeywell Federal Manufacturing \& Technologies P.O. Box 419159 Kansas City, Missouri, 64141-6159 


\section{Honeywell}

KCP-613-Xxxx

Distribution Category UC-Xx

Approved for public release; distribution is unlimited.

FEASIBILITY STUDY - USING A SOLAR EVAPORATOR TO REDUCE THE METALWORKING FLUID (MWF) WASTE STREAM

L. J. Lazarus

KCP-613-8522

Published September 2008

Final Report

Project Team:

D. L. Brown, SE2

E. E. Vance, SE2

B. Reed, SE2

K. Klein, 821

R. Griffith, 821 



\section{Contents}

Section Page

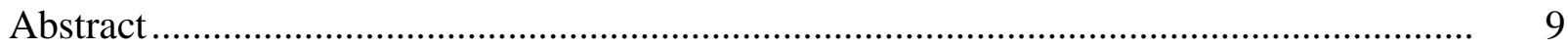

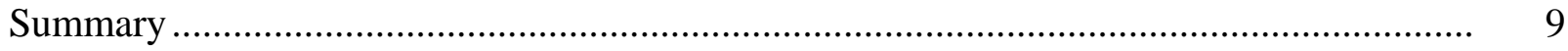

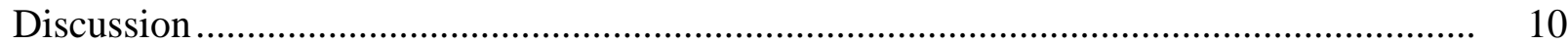

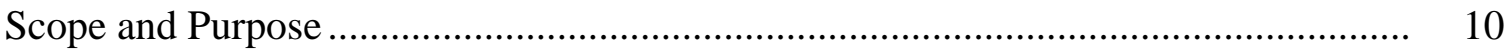

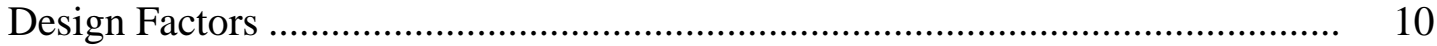

Opportunities.................................................................................. 14

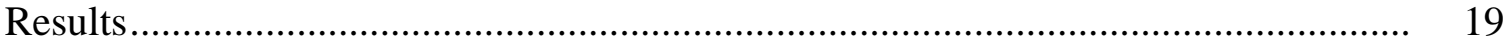

Conclusions and Recommendations ................................................................. 25

Appendix

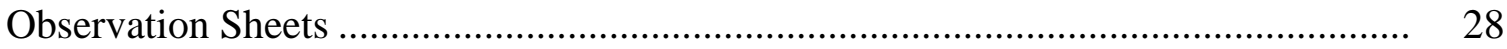




\section{Illustrations}

Figure Page

1 Evaporator with rain shield installed, after 4 inch rain ......................................... 10

2 Copper manifold - Streams distribution fluid over evaporator surface..................... 11

3 First attempt of shield to prevent mist drifting outside tank boundary ..................... 11

4 Evaporator system setup in barrel lot........................................................... 12

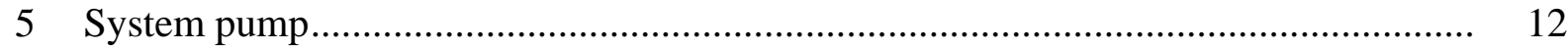

6 Evaporator - oil skimmer components ......................................................... 13

7 Specifications for Oakton Datalogger............................................................ 13

8 J. C. Whitney Gas Gauge sensor and gauge ..................................................... 14

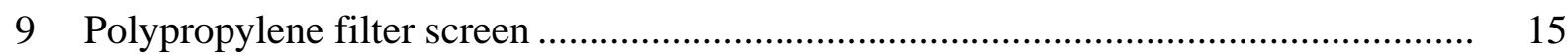

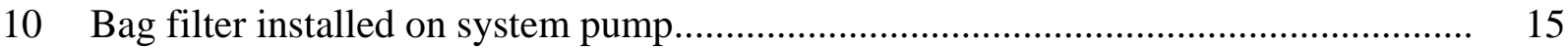

11 Manifold modifications............................................................................. 15

12 Shield to protect bung on 5-gallon waste container........................................... 16

13 Ultrasonic liquid level sensor and specifications............................................ 16

14 Collector extensions installed ..................................................................... 17

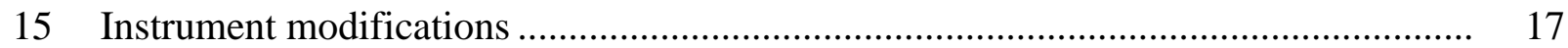

16 Magnetic thermocouple mount under the end of the collector extension................... 18

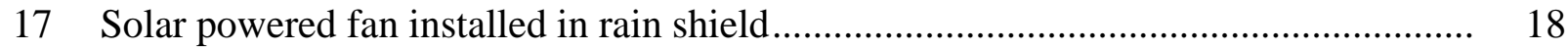

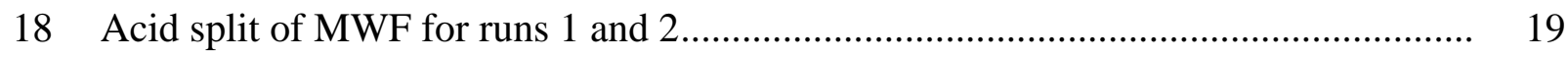




\section{Tables}

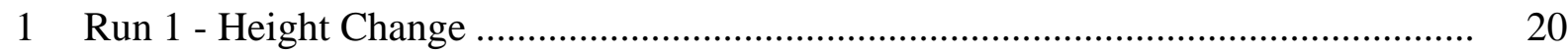

2 Run 2 - Height Change vs. Time ................................................................... 21

3 Run 3 - Height Change vs. Time ................................................................... 22

4 Run 3 - Light Intensity Measurement vs. Time .................................................... 23

5 Run 3 - Temperature Profile Across Collector vs. Time ......................................... 23

6 One Month of Temperature Cycles................................................................. 24

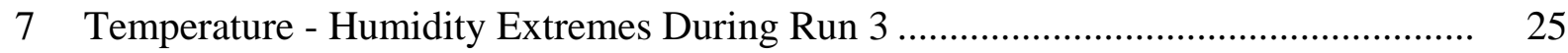




\begin{abstract}
A solar evaporator was designed, built, and operated to reduce the water-based metalworking fluid waste stream. The evaporator was setup in Waste Management's barrel lot inside one of the confinement areas.

The unit processed three batches of waste fluid during the prototype testing. Initial tests removed $13 \%$ of the fluid waste stream. Subsequent modifications to the collector improved the rate to almost $20 \%$ per week.

Evaluation of the risk during operation showed that even a small spill when associated with precipitation, and the unit placement within a confinement area, gave it the potential to contaminate more fluid that what it could save.
\end{abstract}

\title{
Summary
}

A solar evaporator was designed, built, and operated to reduce the water-based metalworking fluid waste stream. The design was intentionally kept as simple as possible. The evaporator was built on an aluminum frame and was sized on the largest available stock tank that could be purchased. Liquid wastes are collected in pails ( 5 gallon), barrels (55 gallons) and carboys (250 gallons). This combination worked out well because we could process one carboy at a time. The evaporator was setup in Waste Management's barrel lot inside one of the confinement areas. Instrumentation was kept simple and later expanded as more questions were asked. The fluid height sensor failed because of corrosion and had to be replaced with an ultrasonic monitor.

The unit processed three batches of waste fluid during the prototype testing. Initial tests removed $13 \%$ of the fluid waste stream. Subsequent modifications to the collector improved the rate to almost $20 \%$ per week by the third run. A number of shields were added to prevent any contamination from escaping the confines of the stock tank. Also many problems were encountered with the delivery manifold. Hole size was modified four times and finally a filter had to be added to the input of the system pump to prevent debris from plugging the manifold.

Evaluation of the risk during operation showed that even a small spill when associated with precipitation, and the unit placement within a confinement area, gave it the potential to contaminate more fluid that what it could save. A number of risk factors, suggestions, and conclusions can be found in the conclusions and recommendation section of this report. 


\section{Discussion}

\section{Scope and Purpose}

Used and/or spoiled metalworking fluids represents one of the largest waste streams for the Kansas City Plant operation. Two types of metalworking fluids are used in FM\&T operations: water-based and oil-based fluids. Water-based fluids are a mix of an oil concentrate and from 90 to $95 \%$ water. It costs FM\&T $\$ 0.52$ per gallon to get this waste fluid removed from the site, properly treated per state and federal regulations, and discarded. The object of this study was to build a small solar evaporator to evaporate part of the water portion of the water-based fluid to reduce the quantity of the waste stream.

\section{Design Factors}

Research was begun on various solar evaporators. A design was proposed and built based on the largest oval stock tank available, manufactured by McMaster-Carr with a capacity of 330 gallons of fluid in a galvanized tank 96 inches long x 36 inches wide x 24 inches deep (see Figure 1). This tank matched well with the 250-gallon capacity waste carboys used by the waste management organization to remove liquid wastes.

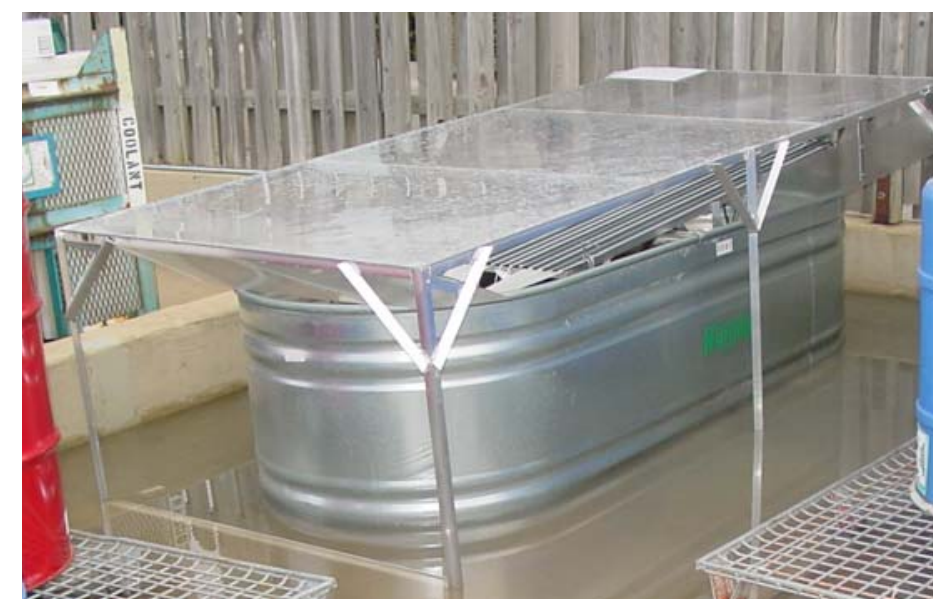

Figure 1. Evaporator with rain shield installed, after 4 inch rain (The inside of the stock tank was dry; note the depth of rain accumulation.)

The evaporator element (see Figure 2) was made from corrugated galvanized sheet that was powder coated black to absorb as much of the sun's energy as possible. The corrugations were 1.25 horizontal pitch with 0.25 height. The collector was 31 inches wide by 5 feet in length. There were 25 channels along its width. The corrugated sheet was set on a frame with a 5 degree slope. A copper manifold (see Figure 2) was mounted along the evaporator width at the top end. The manifold had 0.028 inch holes along it length at 1.25 inch intervals so that the fluid could be distributed along the top end of the galvanized sheet. 


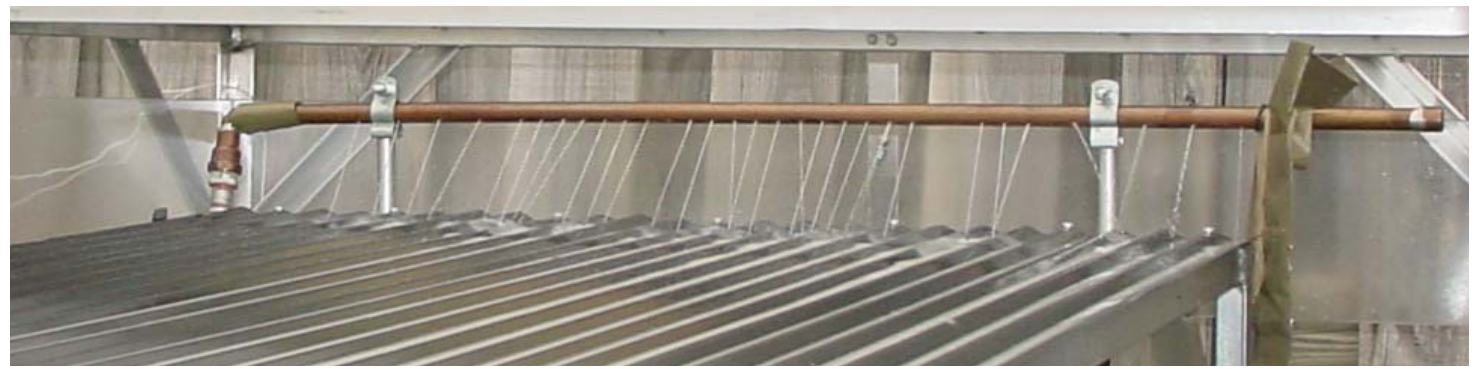

Figure 2. Copper manifold - streams distribution fluid over evaporator surface

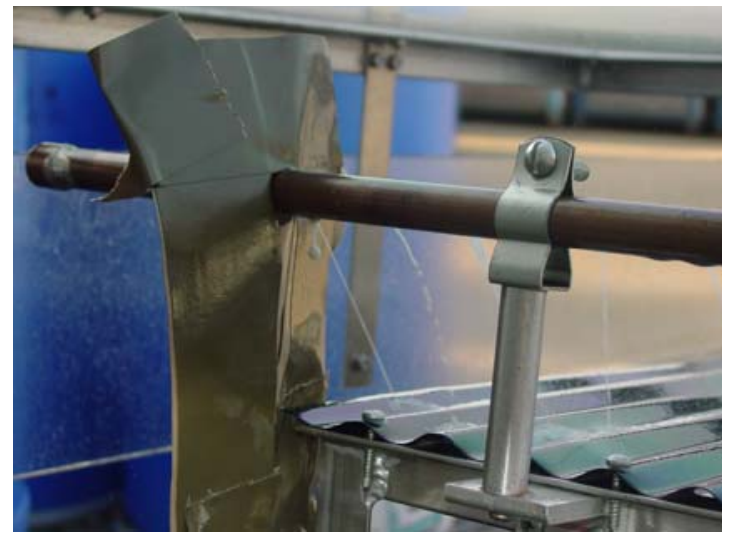

Figure 3. First attempt of shield to prevent mist drifting outside tank boundary

A rain shield (see Figure 1) was designed to prevent rain from mixing with the Metalworking Fluid (MWF) being evaporated. The rain shield built was a 4 foot by 9 foot, 0.125 thick Plexiglas sheet supported by an aluminum angle iron frame. The rain shield had a 3.5 degree slope. A Plexiglas piece 6 inches wide sloping in the opposite direction was placed on the underside. This piece directed the flow back into the tank and prevented any condensate that formed over night to spill out of the system. The gap at the manifold end (head) of the unit was 12 inches above the tank and 6 inches above the collector. The gap at the foot end was 6 inches above the tank. On the rear end of the rain shield, where the gap was largest above the tank, a 4 inch side shield was installed to prevent wind from blowing the fluid out of the unit.

The evaporator was installed in the waste management barrel lot (see Figures 1 and 4) This lot is regulated by federal and state pollution prevention departments and monitored by the FM\&T Environmental Operations department. Since the evaporator unit sat at a low point in a confinement area, any overflow or spray from the evaporator system had the potential to contaminate any rain water that collected and turn it into treatable waste. To prevent this, the drain valve for the area was closed if threatening weather was observed. Any accumulated rain water is inspected for cloudiness or oil floating on the surface. If no contamination is found, the accumulation is released into a storm drain. These concerns resulted in extremely tight operating parameters since a small release from the evaporation unit could result in the generation of hundreds of gallons of treatable waste. 


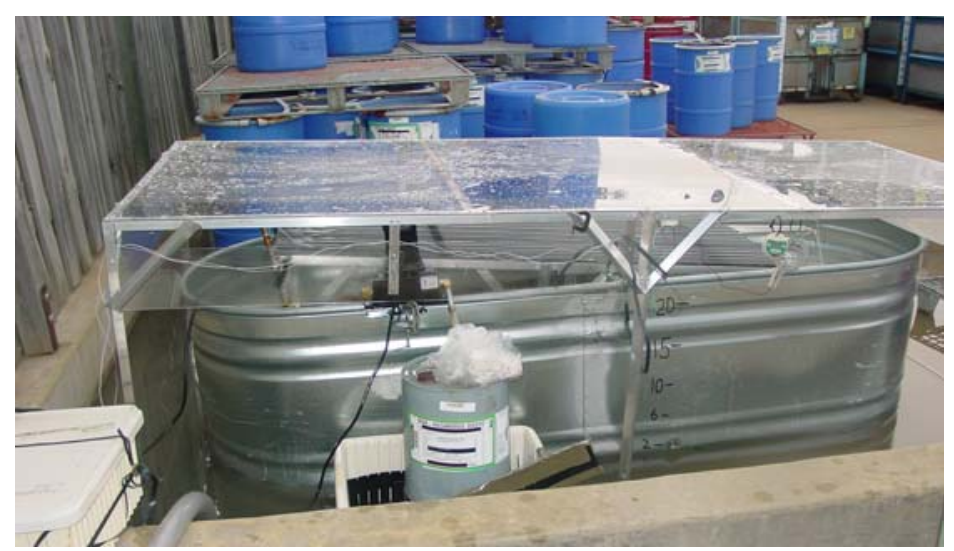

Figure 4. Evaporator system setup in barrel lot

The system was circulated using a UL listed, Little Giant Model 4E-34NR 1/12HP submersible pump (see Figure 5). The pump was capable of pumping 810 gallons per hour at one foot, or raising the fluid 24.5 feet. The pump runs on 110 VAC with a low power requirement. Similar pumps have been successfully used with other MWF applications.

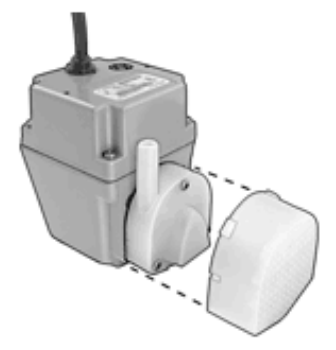

Figure 5. System pump

A Zebra Sidewinder Tube Skimmer (see Figure 6) was also attached to remove way oil (oil residue found in carboys and separated oil from spoiled fluid). This skimmer removes oil at a maximum rate of 1 quart/hour. The skimmer was mounted on top of a diverter. The lock jaw mounting plate was bolted to the bottom of the diverter. The whole assembly was then clamped to the top lip of the tank. This unit also runs on 110 VAC power. The oil side of the diverter was connected to a tube that ends in a 5-gallon waste oil container with a waste management designation of Oil L2, a non-hazardous waste oil container. The oil container was set in a separate confinement tank to prevent spills in handling the catch can from contaminating the area. The water side of the diverter returned the water-based component back to the stock tank. The waste oil can be fuel blended. If the MWF has over $10 \%$ oil it is considered hazardous waste which requires a much higher cost per gallon disposal cost. 


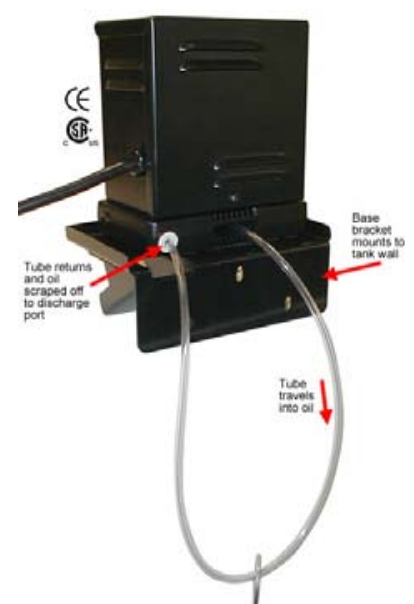

Sidewinder Skimmer

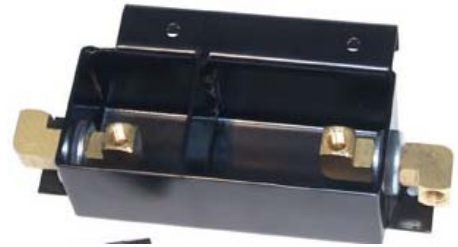

Diverter - Separates Water from Oil

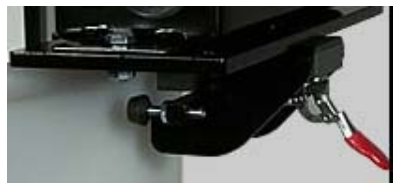

Lockjaw Clamp

Figure 6. Evaporator - oil skimmer components

A minimal amount of instrumentation was incorporated to track the evaporator operation. An Oakton Temperature/Humidity Datalogger (see Figure 7) was used to track the environment around the evaporator. This instrument was attached to a 0 to 10 VDC device to interface a fuel gauge from J C. Whitney (see Figure 8) to track fluid level. This proved unsuccessful because components of the float system were made of iron and quickly rusted to failure (first two weeks of operation) in the water-based environment. The fluid level was tracked by reading a 24-inch steel machinist scale that was clamped to one of the collector's legs that sat inside the stock tank. We did use the datalogger to track changes within the evaporator environment.

\section{OAKTON ${ }^{\circledR}$ Temperature/Humidity Dataloggers}

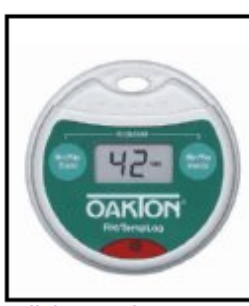

click to enlarge

\begin{tabular}{|c|c|}
\hline $\begin{array}{l}\text { R-35710-10 } \\
\text { Dakton }{ }^{\circledR H} / \text { TempLog } \\
\text { Temperature/ Humidity } \\
\text { Datalogger }\end{array}$ & $\begin{array}{l}\text { Qty: } 1 \\
\text { Add to Cart }\end{array}$ \\
\hline$\$ 160.00 /$ each (USD) & In stock. \\
\hline
\end{tabular}

- Compact, rugged housing guarantees operation in busy areas, laboratories, cold rooms, and more

- Sample from once per 10 seconds to once per 2 hoursbuilt-in clock and calendar track your data in real time

- Quickly document min/max values with optional IR printer

- Built-in clock and calendar track your data in real time

These loggers store up to 16,000 measurements, allowing you to track important temperature and humidity data for months. The two-digit LCD shows current conditionsminimum and maximum readings are available at the touch of a button. If set limits are passed, the built-in alarm flickers the display and must be manually reset. Use the external sensor input to add one additional sensor (sold separately) to your datalogger.

Model 35710-00 records temperature and features a waterresistant IP65-rated housing. Model 35710-10 records temperature and humidity and features a dustproof IP60rated housing. Datalogger kits include datalogger, software and cable.

35710-00 \& 35710-10 Loggers require 35710-50 software/cable if not used with $35710-20$ cradle \&. sofware/cable if not

\begin{tabular}{|c|c|}
\hline RH range & 0 to $100 \% \mathrm{RH}$ \\
\hline RH resolution & $0.5 \% \mathrm{RH}$ \\
\hline RH accuracy & $\begin{array}{l} \pm 3 \% \mathrm{RH} \text { from } 0 \text { to } 90 \% \mathrm{RH} \\
\pm 6 \mathrm{RH} \text { from } 90 \text { to } 100 \% \mathrm{RH}\end{array}$ \\
\hline Temp range & -30 to $50^{\circ} \mathrm{C}\left(-22\right.$ to $\left.122^{\circ} \mathrm{F}\right)$ \\
\hline Temp resolution & $0.5^{\circ} \mathrm{C}\left(1.0^{\circ} \mathrm{F}\right)$ \\
\hline Temp accuracy & $\pm 0.6^{\circ} \mathrm{C}\left( \pm 1.1^{\circ} \mathrm{F}\right)$ \\
\hline Battery life & Approx. 2 years \\
\hline Display & Two digit LCD display, $3 / 8 " \mathrm{H}$ \\
\hline Output & $\begin{array}{l}\text { Infrared: IRDA interface to printer or } \\
\text { computer with IRDA port } \\
\text { RS-232: cable connection to your } \\
\text { computer (order cable/software } \\
\text { package separately) }\end{array}$ \\
\hline Sampling rate & $\begin{array}{l}\text { Selectable via software from once per } \\
10 \text { seconds to once per two hours }\end{array}$ \\
\hline Memory & 16,000 data points \\
\hline Housing & IP60 rated \\
\hline Power & $3.6 \mathrm{~V}$ lithium battery \\
\hline $\begin{array}{l}\text { Manufacturer } \\
\text { number }\end{array}$ & EC650 \\
\hline
\end{tabular}

Figure 7. Specifications for Oakton Datalogger 


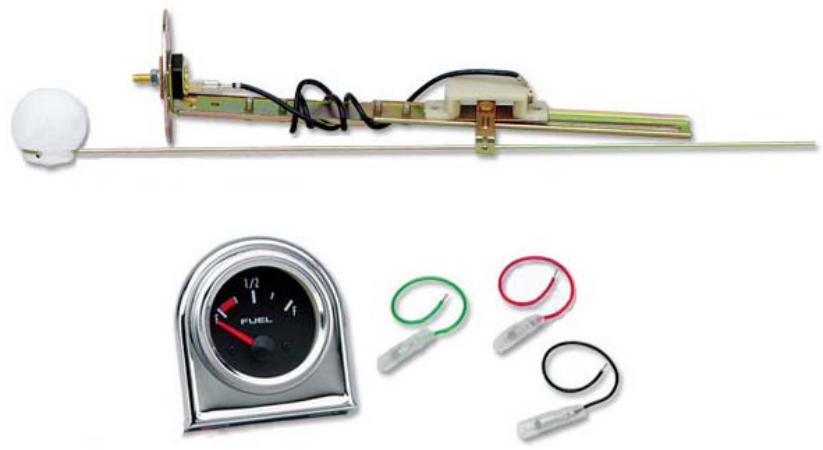

Figure 8. J. C. Whitney Gas Gauge sensor and gauge

\section{Opportunities}

Numerous problems and changes were required during the first run. These are noted in the daily logs. The first problem to be addressed was the prevention of any leaks that might contaminate the area. A number of changes involved the supply manifold. As the MWF flowed though the small holes at low pressure, buildup occurs, eventually clogging the holes in the manifold. Also, the fluid used for this process was waste fluid containing a lot of debris. As the debris builds up in the holes, the pressure in the manifold builds up and instead of streaming on the collector the fluid sprays out the holes. This creates a problem at the ends of the manifold where the spray can spill out of the stock tank onto the ground. Many variations of shield were tried to prevent this. The final design included a one foot long, 90 degree angle that was formed out of sheet metal starting at the manifold. A piece of vinyl strip door material was attached to the outside of the sheet metal, containing the spray at the end of the manifold.

Another problem discovered was seepage at the bottom seam of the tank caused by a small dent from handling damage. This seepage combined with the accumulated dirt that was carried into this area due to the slope of the ground which held the fluid, allowed water to wick under the stock tank. After the first rain and the obvious oil film around the base of the tank it was evident that more waste was being created than saved by evaporation. This seepage was controlled by using RTV on the outside seam. The inside seam was also covered with RTV between the first and second runs.

The third batch of fluid processed in the evaporator was fluid residue from chips sent for disposal. Even with holes enlarged five times from the initial 0.028 diameter to over 0.063 inch diameter, there was so much debris the manifold would clog in minutes. The rough polypropylene filter screen (see Figure 9) was not adequate for handling this combination of slug and debris. 


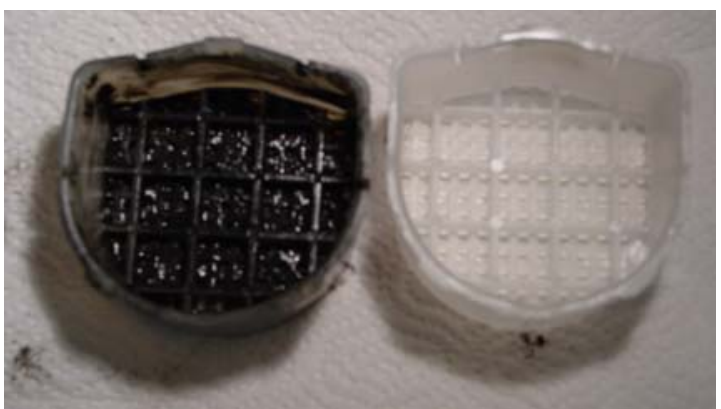

Clogged screen and new screen

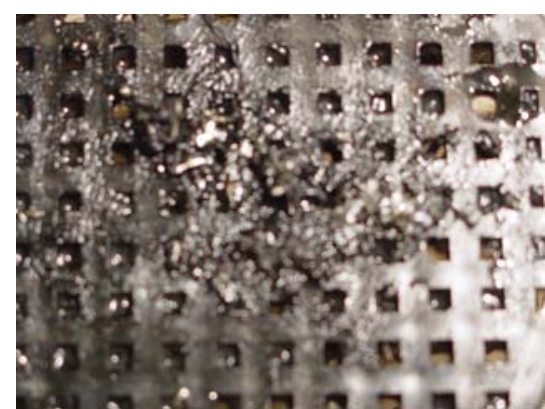

Detail of clog

Figure 9. Polypropylene filter screen

The screen was replaced with a trade size 9, 100/200 micron felt filter bag that was 5.5 inch diameter and 32 inches long. Rings were fitted to the inside of the bag to keep its shape and the end was tied to a piece of $3 / 4$ schedule 40 pipe connected to the input to the pump (see Figure 10).

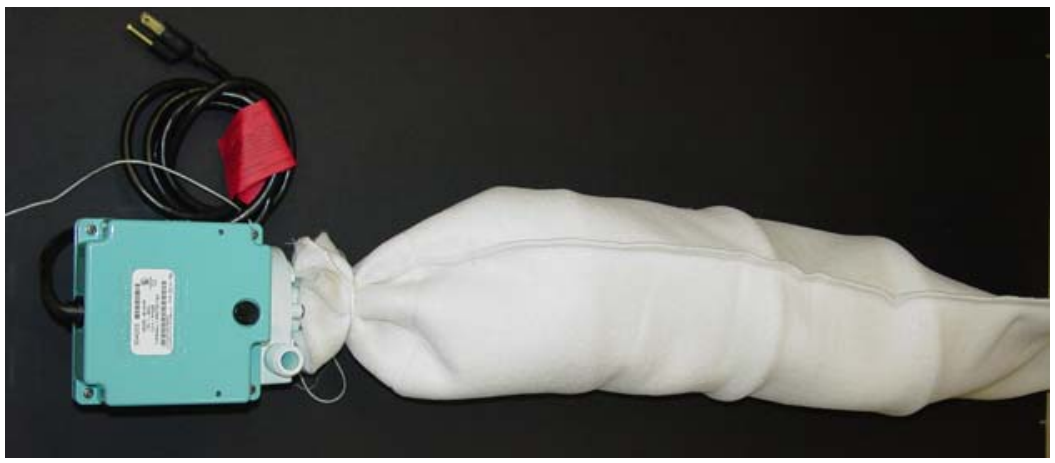

Figure 10. Bag filter installed on system pump

The combination of filter bag and hole size solved the manifold plugging problem. The other modification made to the manifold was the installation of valves in the supply line (to regulate flow) and a tee (for the addition of a branch line) (see Figure 11). An 1/8 inch branch line was installed in the stock tank and used as a fountain. This also set up a flow on the top surface around the inside edge of the stock tank and brought the oil floating on the top to the skimmer.

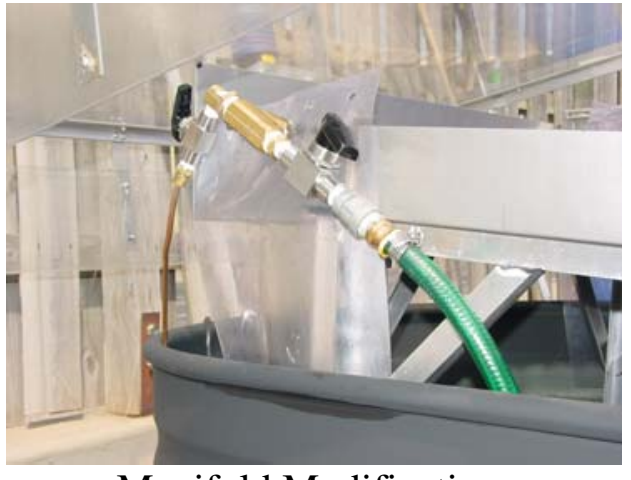

Manifold Modification

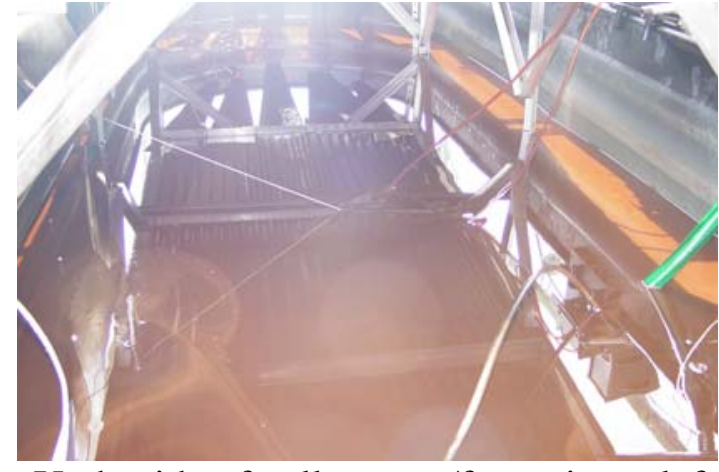

Underside of collector w/fountain on left side and skimmer tube on right side

Figure 11. Manifold modifications 
To prevent rain from entering the 5-gallon oil waste can, a shield was fabricated (see Figure 12) from a funnel over the open bung on the can.

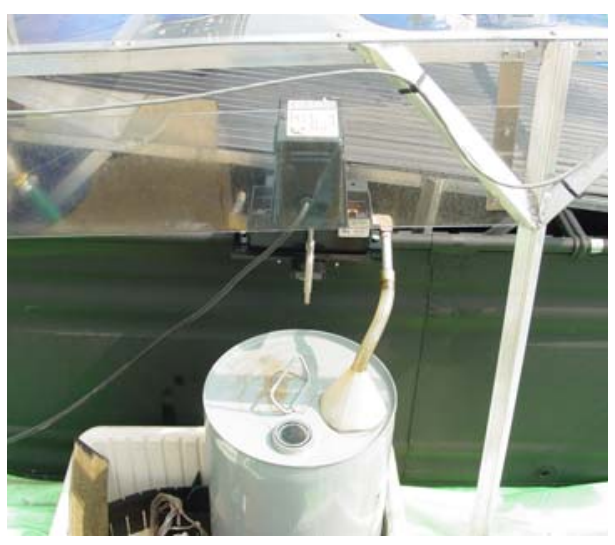

\section{Figure 12. Shield to protect bung on 5-gallon waste container}

Another modification was the replacement of the fluid height measuring device (see Figure 13). This was the most costly of all the modifications. An ultrasonic liquid level height indicator was purchased from Omega Engineering Co. (see specifications below). the combination power supply and controller was also purchased for future applications such as the ability to remotely monitor the fluid level.

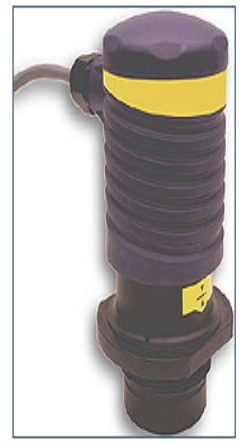

- $8^{\circ}$ Beam Allows Application in Restricted Environments

- All Plastic Construction

- LED Digital Display Indicates Level in Inches or Centimeters

- Push Button Calibration For All User Set Points

- Built-in 10A Relay May Be Configured For Alarm or Automatic Fill Empty Operations

- Fail-Safe Relay Logic Provides Echo and Power Loss Safety

- Sanitary Model Available

View related products - Level Measurement

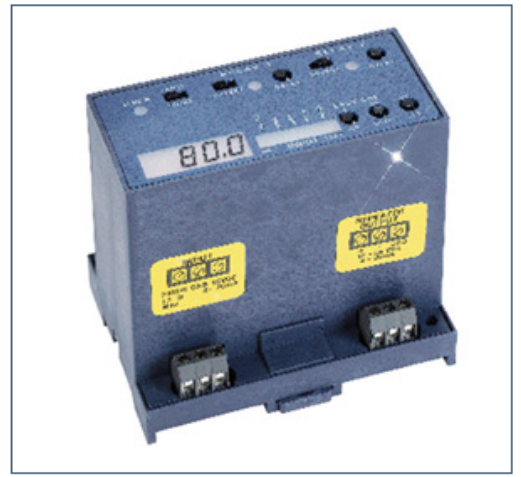
Setpoints
SPECIFICATIONS

Range: 0.5 to 24.5 feet

Accuracy: $\pm 0.25 \%$ of span

Resolution: $0.125^{\prime \prime}$ ( $3 \mathrm{~mm}$ )

Frequency: $50 \mathrm{kHz}$

Pulse rate: 8 pulses/second

Blocking distance: 6 " minimum

Display type: 4 segment LED

Display units: Inch / $\mathrm{cm}$

Supply voltage: $14-36$ vd

Consumption: $200 \mathrm{~mA}$

Current flow: Source / sink

Signal output: 4-20 mA, 12-36 vdc

Signal averaging: Fast / slo

Calibration: Push button

Relay output: 250 VAC, 10A, $1 / 2 \mathrm{hp}$, SPDT

Relay indication: ON / OFF status

Eontact resistance: 30 milit,

Fail-safe diagnostic. Relay reverts to safe position

Temperature rating: -40 to $60^{\circ} \mathrm{C},\left(-40\right.$ to $140^{\circ} \mathrm{F}$ )

Pressure rating: 30 psi (102 $25^{\circ} \mathrm{C}$., derated (01.667 psi per ${ }^{\circ} \mathrm{C}$. above $25^{\circ} \mathrm{C}$.

Pressure rating: 30 psi

Enclosure

Enclosure material: Ponsducer material: PWDF

Mounting threads: 2" N.PT (4" female with " $-S^{\prime \prime}$ option)

$\$ \mathbf{4 2 5 . 0 0}$ LVGN-51

- Universal Proportional Controller with Adjustable

- Numerical Display and Bar Graph Assists in Programming

- Excellent Choice for Use with Continuous Ultrasonic and RF Capacitance

- Isolated 4 to $20 \mathrm{~mA}$ Proportional Output Reversible

- Time Delay Feature Dampens Alarm Chatter

- Auto Fill or Empty Capability with Independent Alarm

- Scaleable in Engineering Units

View related products - Level Measurement

Figure 13. Ultrasonic liquid level sensor and specifications 
It was observed that readings taken from the steel rule were affected by temperature. Since the sensor device is mounted to the rain shield and senses the fluid level in a steel tank, the combined effects of thermal expansion of aluminum, Plexiglas, steel, and water affected the readings. Day to day readings taken at the same time of day at approximately the same temperature can be compared. This provides an explanation of why no changes in height are noticed during the heat of the afternoon but there are from 0.1 to 0.2 inch change in fluid height. in the morning when everything has stabilized at the same temperature.

Collector extensions, painted black to absorb heat, were also added to the side walls of the stock tank. These extensions were flat with a small lip on the outside edges. It was observed that the fluid absorbs more heat on the flat section than the corrugated section of the extensions. To absorb more heat to warm the fluid, the stock tank was also painted flat black (see Figure 14).

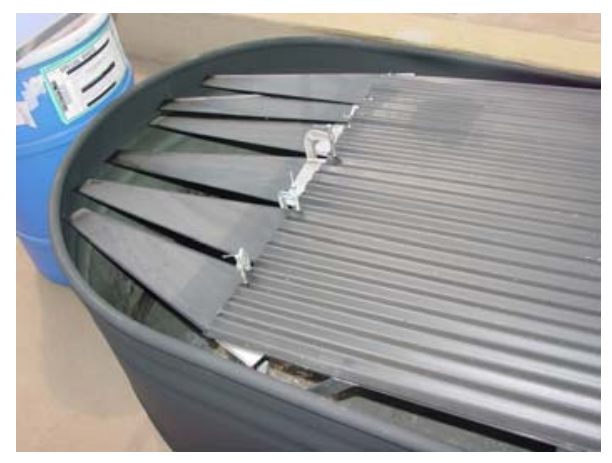

Figure 14. Collector extensions installed

The collection of additional data began during the second run. Thermocouple readings were added along the evaporator surface at the head end, the end of the collector (or tail end), and at the end of the extensions. An additional data point was provided using a meter that measured light intensity in foot candle (see Figure 15).

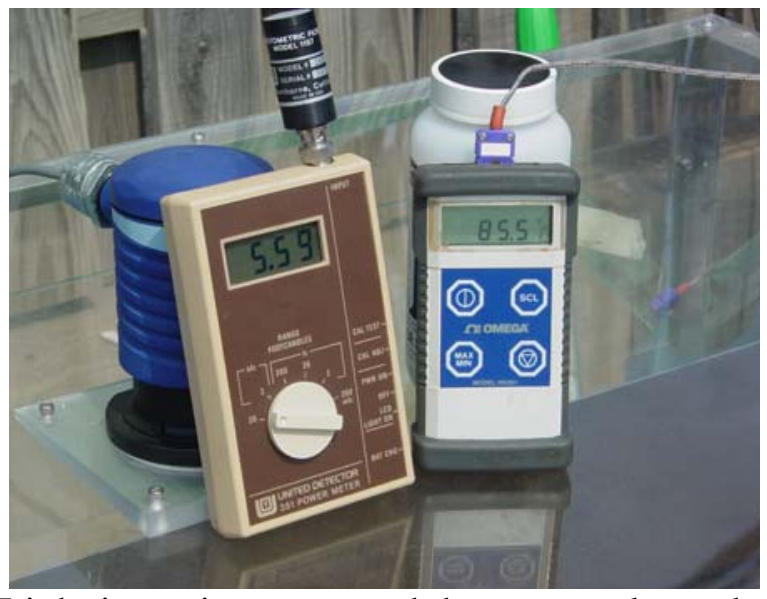

Light intensity meter and thermocouple readout

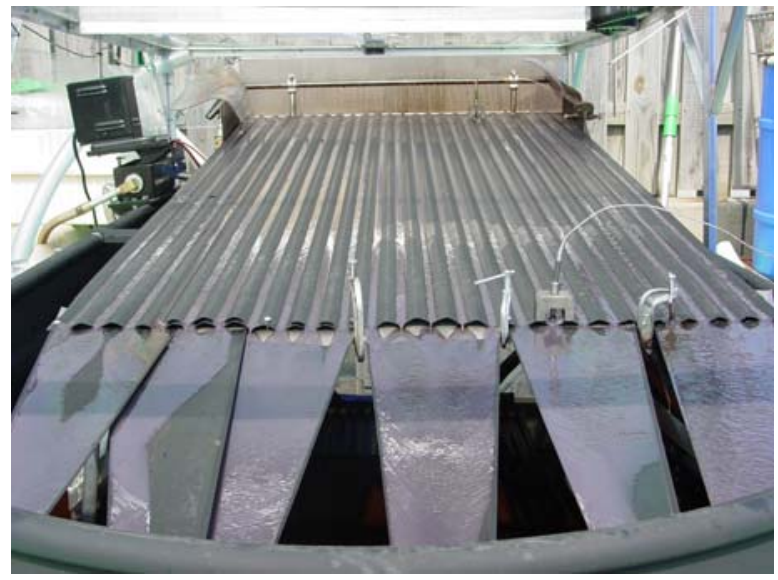

Magnetic thermocouple mounts

Figure 15. Instrument modifications 
Later, thermocouples in spring-loaded magnetic mounts were added. The end mount was mounted upside down (see Figure 16) under the end of the extension so that the temperature of the fluid leaving the collector could be measured. The two magnetic sensors were mounted under the fluid surface so that the fluid temperatures at the head and tail ends could be measured. Using these mounts with connectors allowed the thermocouples to be plugged into the readout to quickly obtain temperature readings.

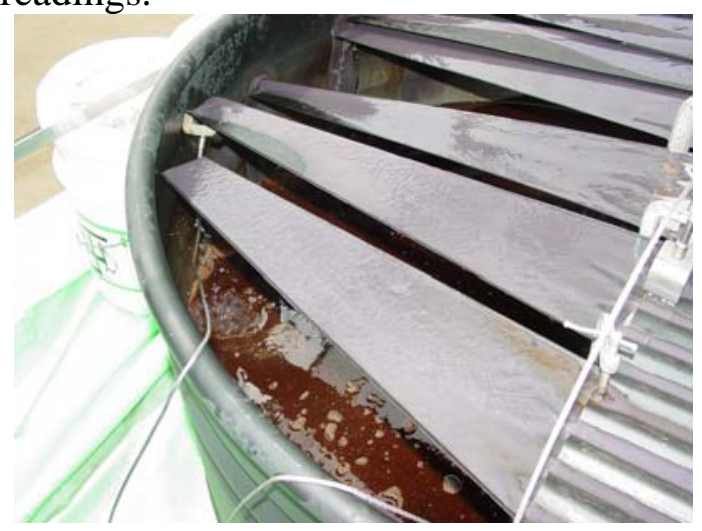

Figure 16. Magnetic thermocouple mount under the end of the collector extension

Another modification made during the second run was the addition a solar-powered fan (see Figure 17) to each side of the underside of the rain shield to draw humid air from above the collector out from under the rain shield into the atmosphere and increase the evaporation rate. However, these fans did not generate very much volume and were not effective.

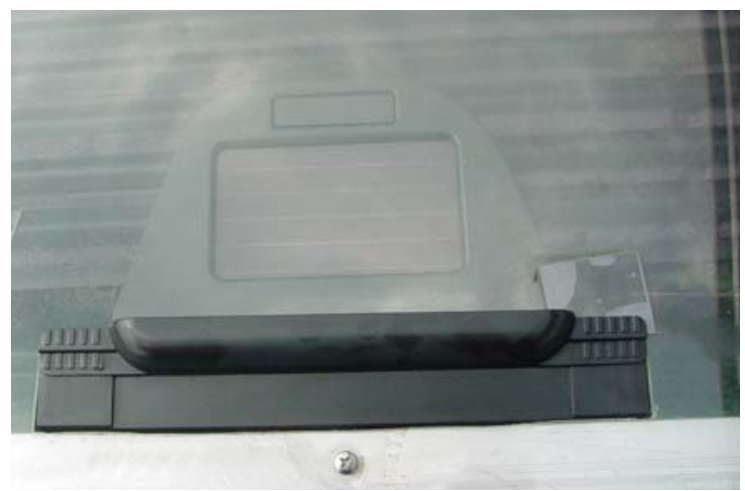

Figure 17. Solar powered fan installed in rain shield

Fluid stability was monitored for the first two runs. Because the fluid was being constantly circulated, no deterioration of the fluid was observed. As expected, acid splits showed the emulsified oil percentage increase during the run. 

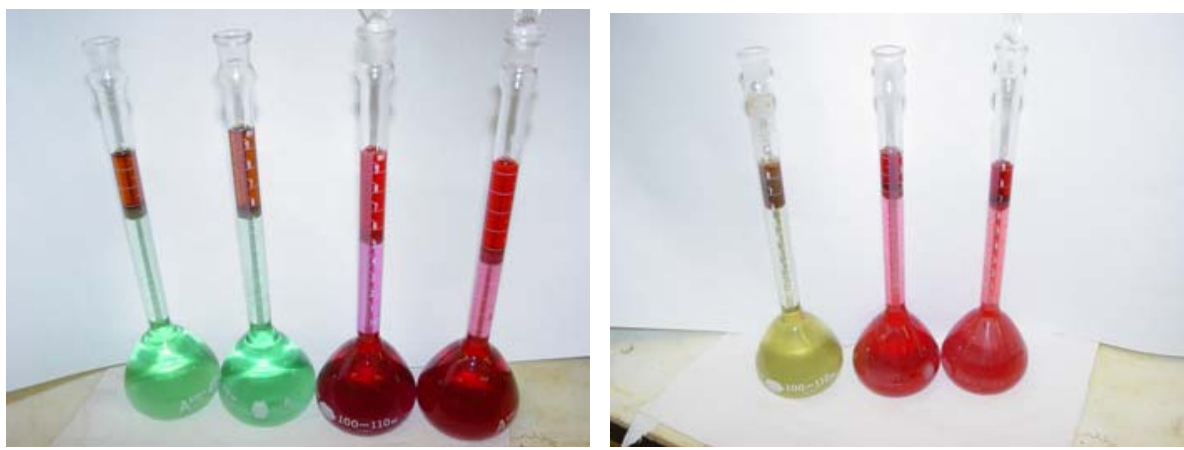

Figure 18. Acid split of MWF for runs 1 and 2

Acid split from the third run was zero because the emulsifier had been destroyed by bacteria.

\section{Results}

The first run of the evaporator system was loaded with a charge of MWF from the quick cleaning process in D/25. The MWF was a $2 \%$ solution of TrimSol heavily dosed with CimClean 30 and Kathon. This solution was used to break up deposits in the MWF system including the sump and to sterilize the surfaces. The fluid had no odor because bacteria and mold counts were zero. There was approximately 5 gallons of oil skimmed off the surface. The fluid level table shows a fairly constant slope. Loss rate was approximately 2 inches per week or approximately 13\% per week. 
There was a significant learning curve for the first run. The reason the initial slope (see Table 1) was steeper was because of the skimmer removing oil from the top surface at its maximum rate for hours. Also affecting the slope was the spray mist that was drifting out of the unit. After this problem was solved with installation of the shield, the slope remained fairly constant.

\section{Table 1. Run 1 - Height Change}

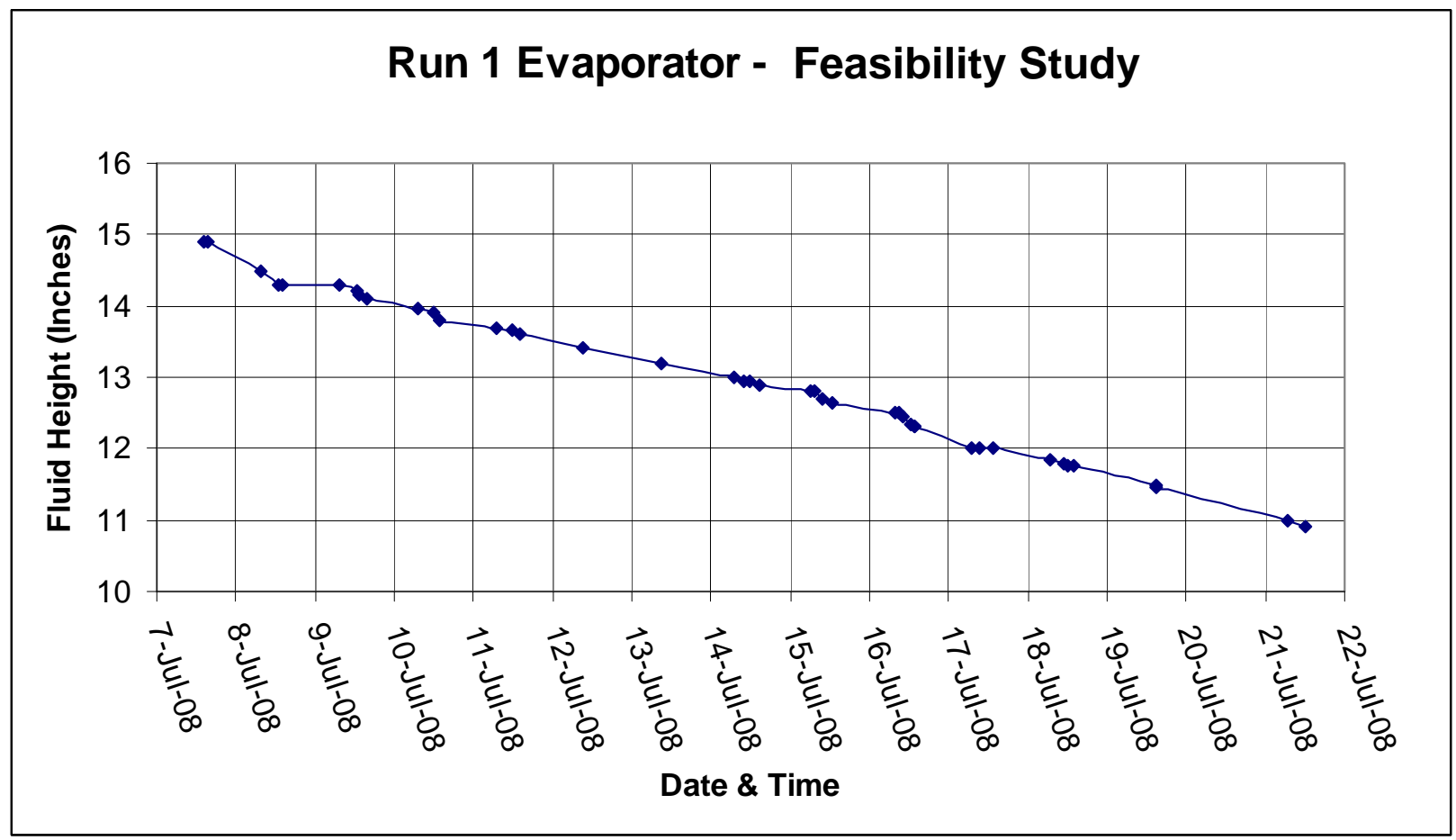


The second run was with another load of $\mathrm{D} / 25$ quick clean fluid.

Table 2. Run 2 - Height Change vs. Time

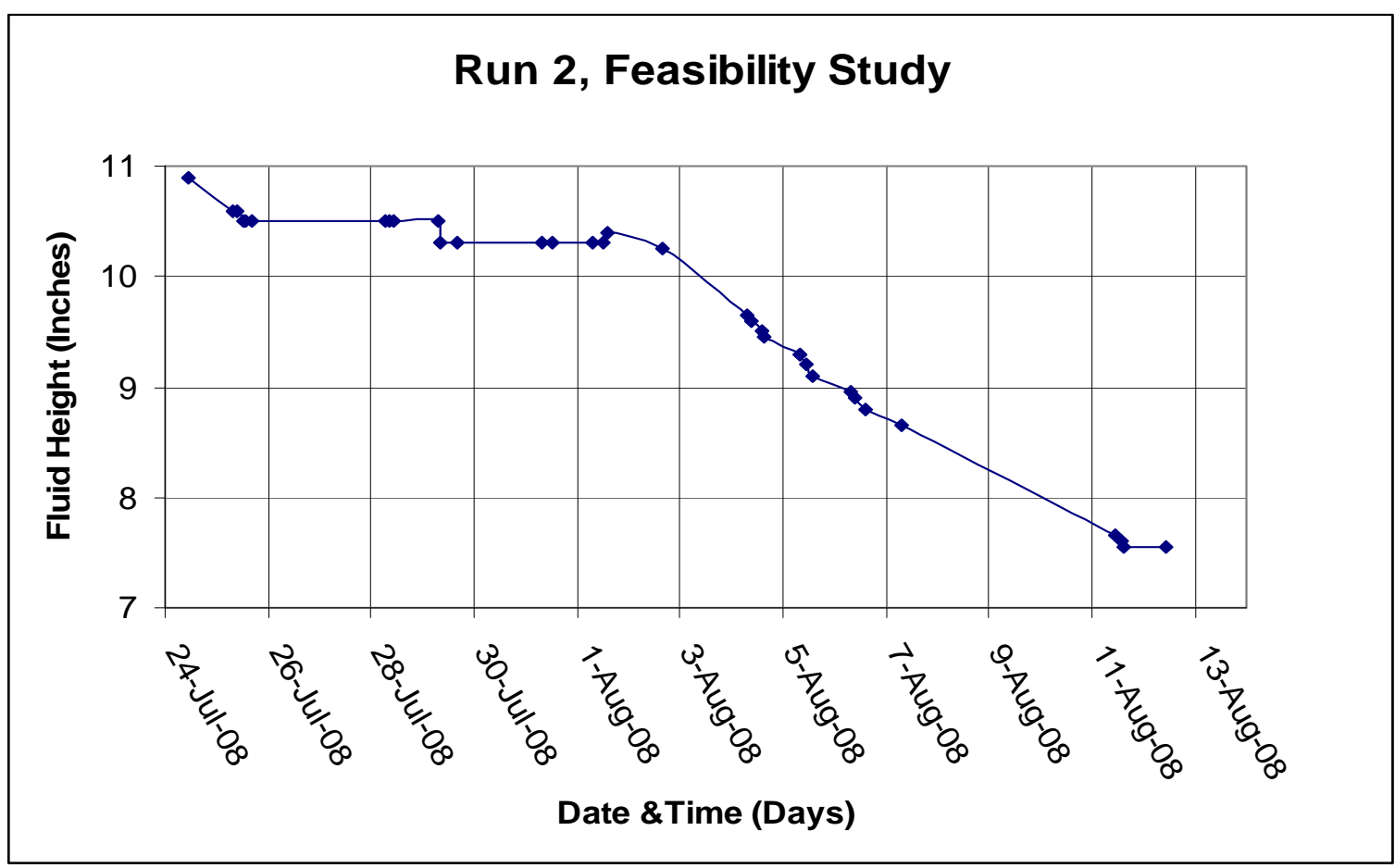

A decision was made not to run the system for a period of days due to modifications that had occurred. Conditions during the next three days of the run were raining with cloud cover. The confinement area filled with water and was not drained so the air around the evaporator was saturated. After conditions cleared and the confinement drained, fluid started to evaporate. The first week resulted in only a $5 \%$ evaporation rate (see Table 2). The effect of the evaporator extension is evident during the second week when the evaporation was almost $17 \%$. For the 18 day run $30.7 \%$ of the fluid volume or approximately 0.19 inches per day was lost.

The third run was from the chip mill area of waste management. All the chip barrels are drained before the chips are processed. This drainage is accumulated in a carboy. The liquid is a mix of every fluid found in the plant along with any other materials that might be tossed into a chip barrel. The fluid was covered by a lot of oil and had spoiled. During spoilage the bacteria attack the emulsifiers in the water-based metalworking fluid and break the solution apart. The $\mathrm{pH}$ of the fluid when checked was 7.1. A typical water-based fluid is alkaline and has a pH from 8.6 to 9.1 in normal operation. When bacteria attack a fluid their waste is acidic. This fluid had been sitting around so long that the batch of approximately 200 gallons was almost neutral.

The fluid had a strong odor to it. In order to not violate area permits, permission was obtained by waste management to add one pound of sodium hydroxide to the fluid to bring it up into the normal alkaline range and slow down the corrosion effects and to add four ounces of odorant to control the odor. 
During the third run, the skimmer removed over 22 gallons of oil floating on the top surface of the fluid. That accounted for the stair-step shape of Table 3. The weather during this run included two partial days of rain and overcast skies.

Table 3. Run 3 - Height Change vs. Time

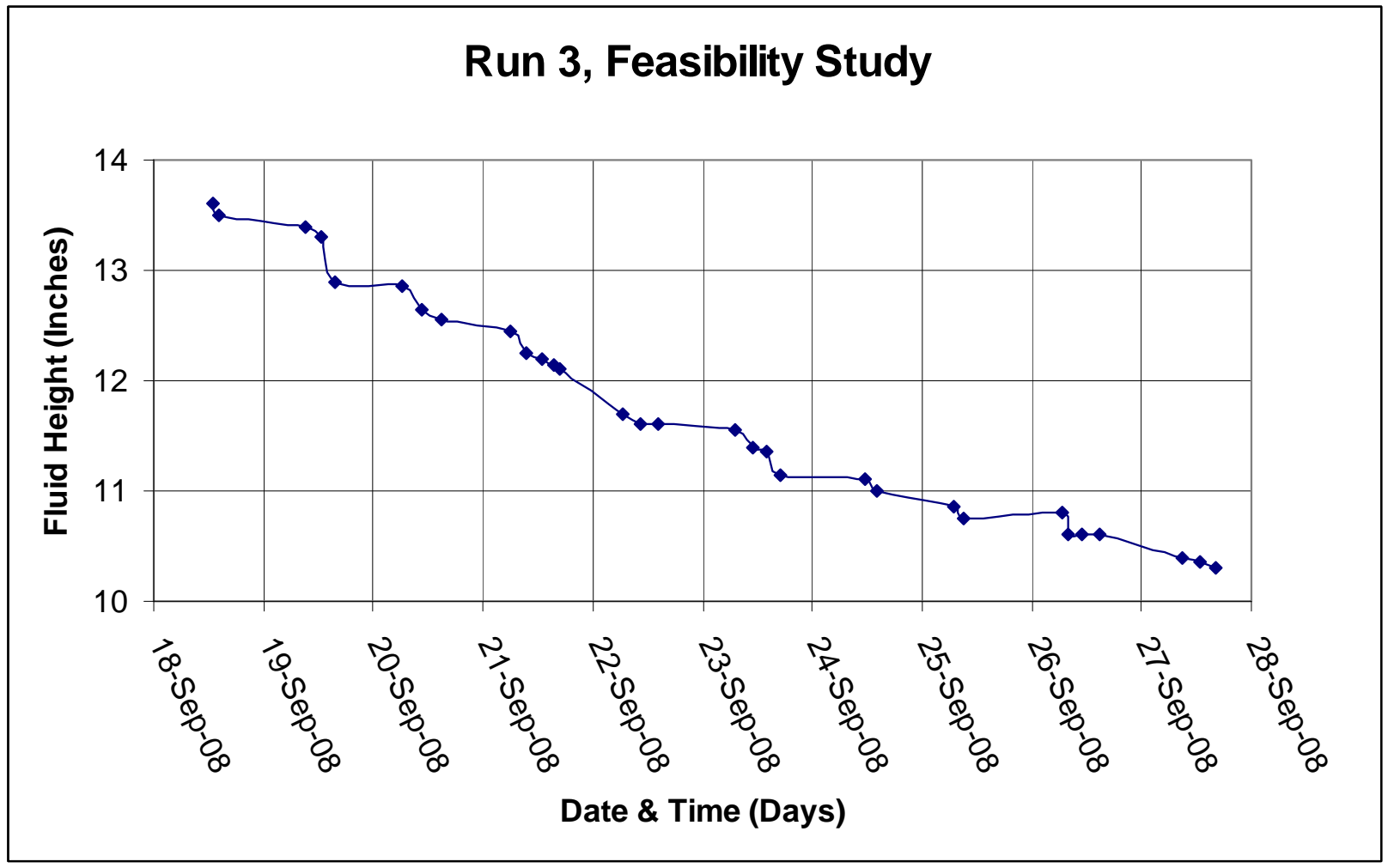

During the 10 days since the run was started (see Table 3), 25\% of the initial charge or approximately $2.5 \%$ per day had been removed. Ten percent of this total was due to the oil that was skimmed off the top surface during the first week. During the last five days approximately 0.2 inches of fluid height per day was removed due to evaporation.

Although the odor from this run got gradually stronger, there were no complaints from personnel in the area. 
The light intensity measurements (see Table 4) show the effects of weather conditions. The slight change in slope of the fluid height is evident in this table. The impact from the light intensity had a striking effect on the temperatures taken along the evaporator surface and the fluid temperatures in the stock tank.

Table 4. Run 3 - Light Intensity Measurement vs. Time

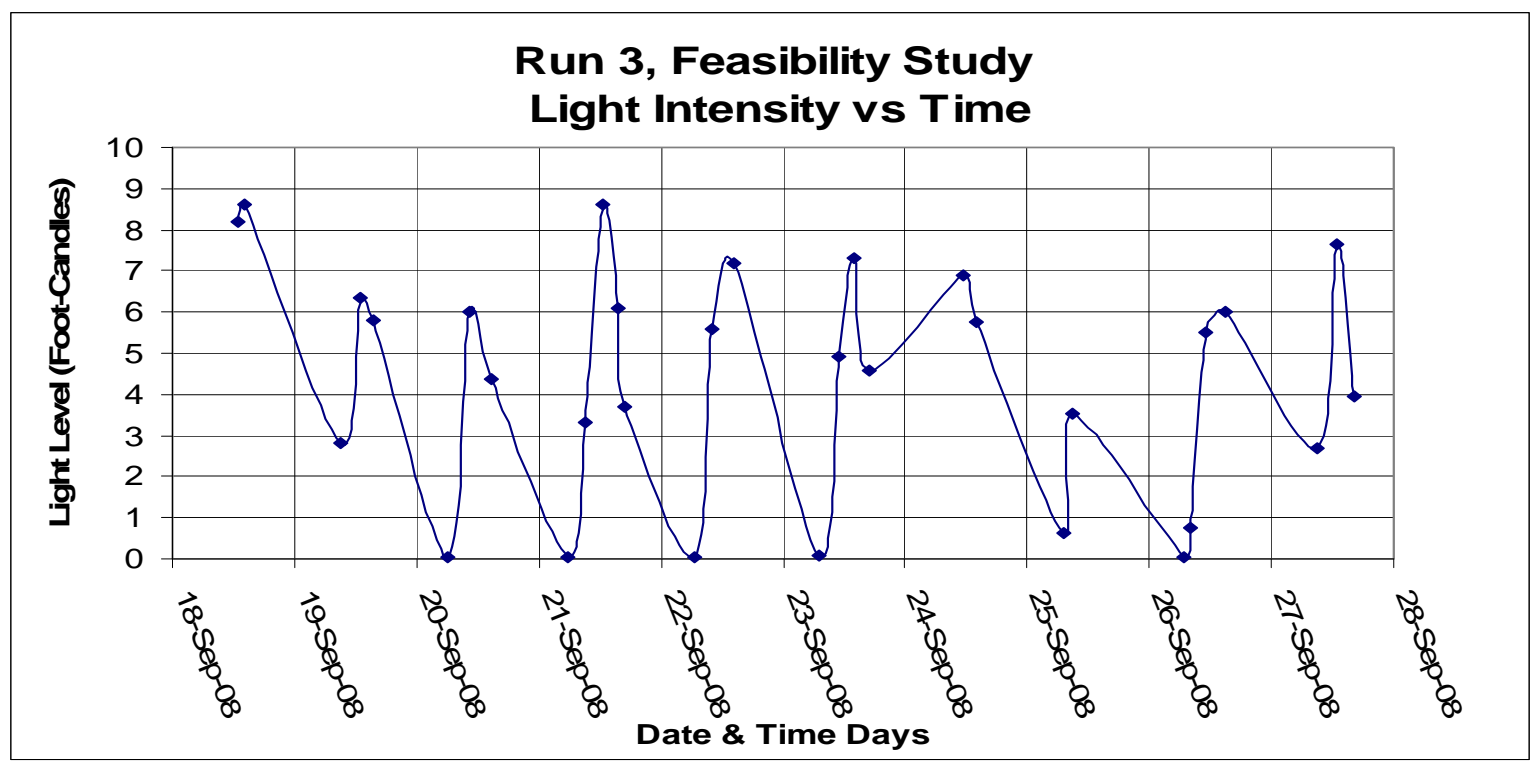

The temperature of the evaporator stayed nearly constant during the daytime on the days with rain and significant cloud cover (see Table 5).

Table 5. Run 3 - Temperature Profile Across Collector vs. Time

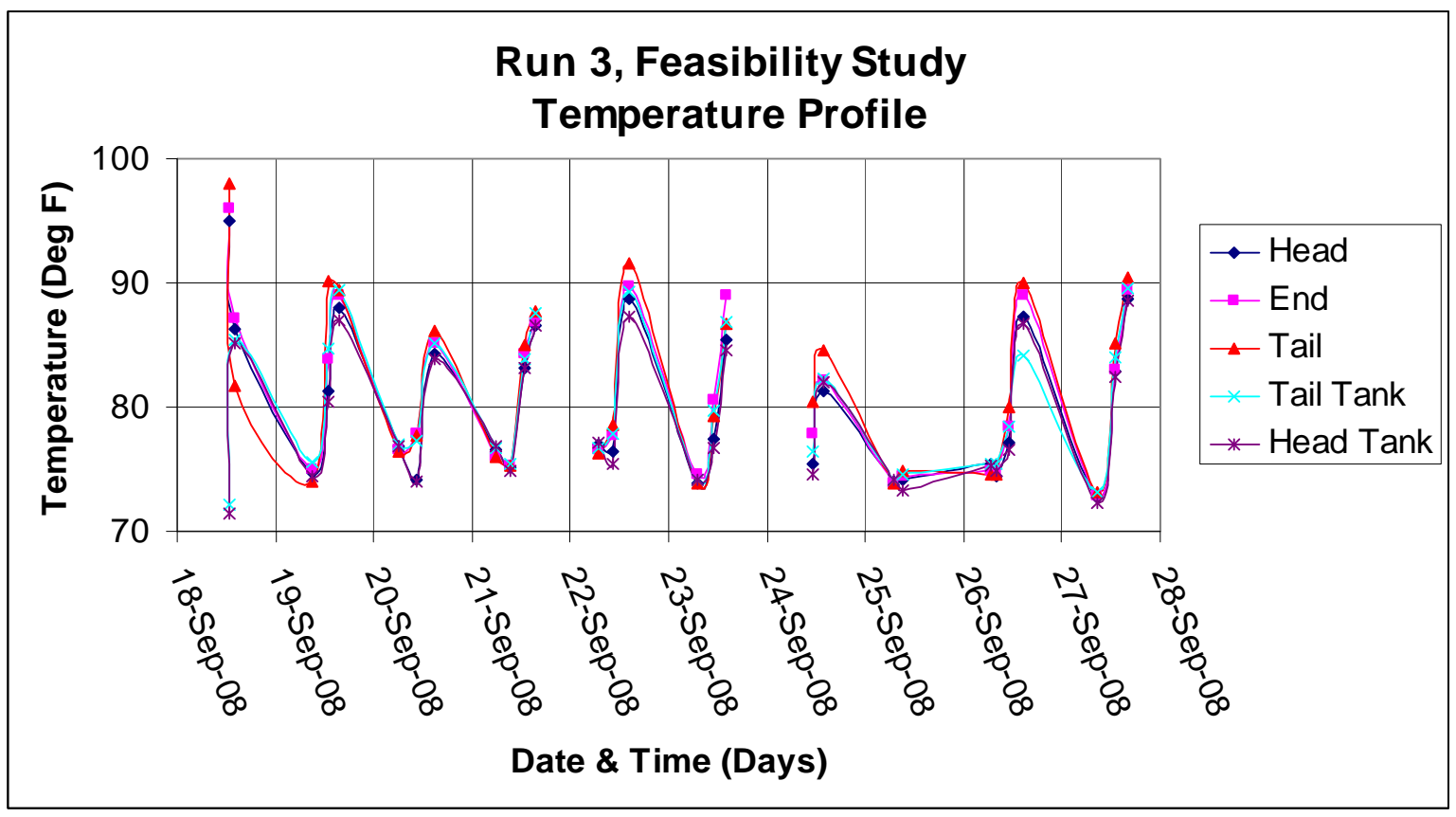


The daily temperature and humidity excursions plotted on top of each other (see Table 6) shows some definite trends. To increase efficiency, the system pump should be shut down from midnight to 8:00 AM. During this period the evaporator acts like a condenser because the temperature extremes flip and the fluid cools as it flows down the surface.

\section{Table 6. One Month of Temperature Cycles}

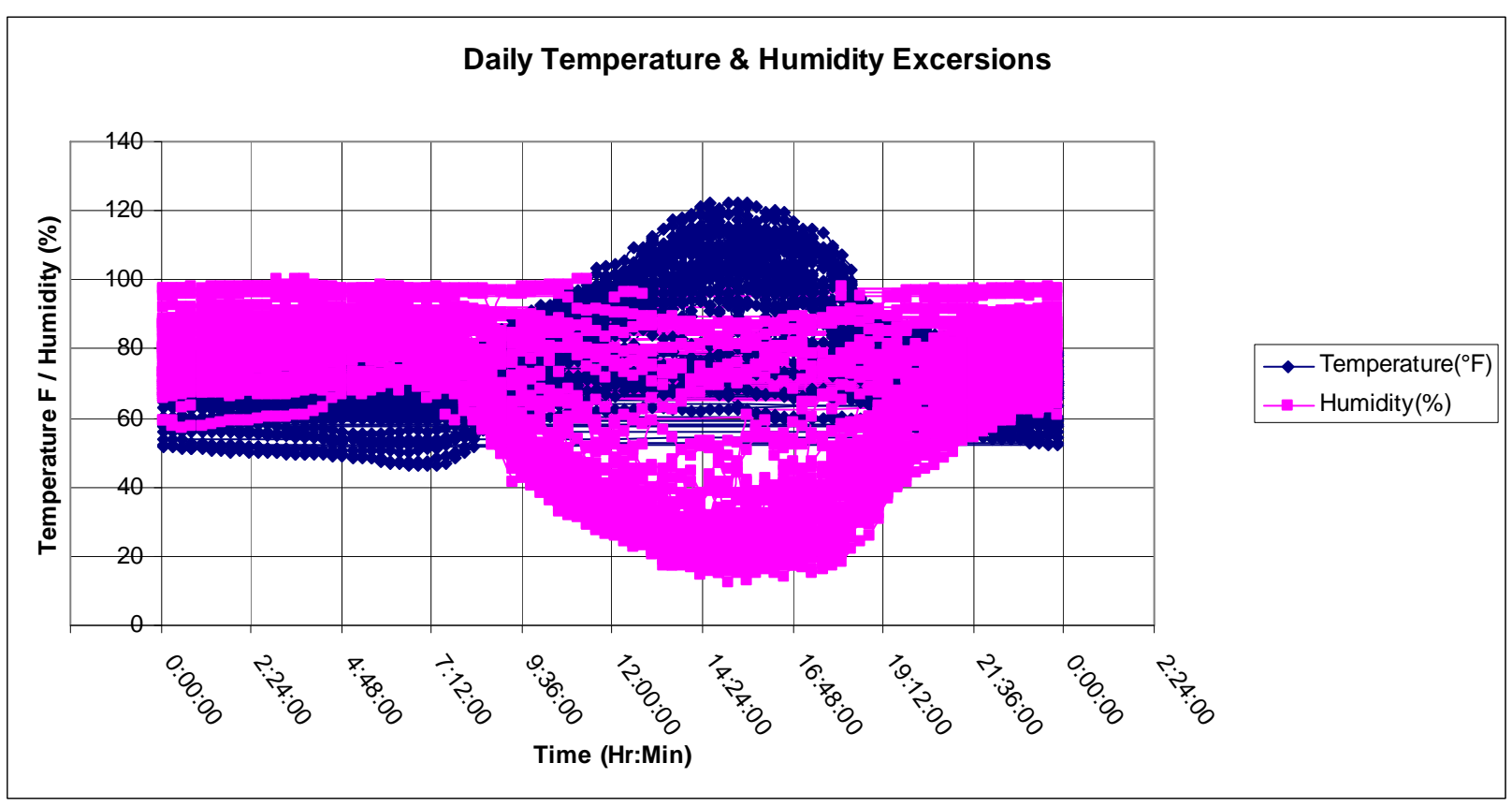


When the data is spread out (see Table 7), it is evident that on certain days nothing significant occurred due to inclement weather and precipitation.

Table 7. Temperature - Humidity Extremes During Run 3

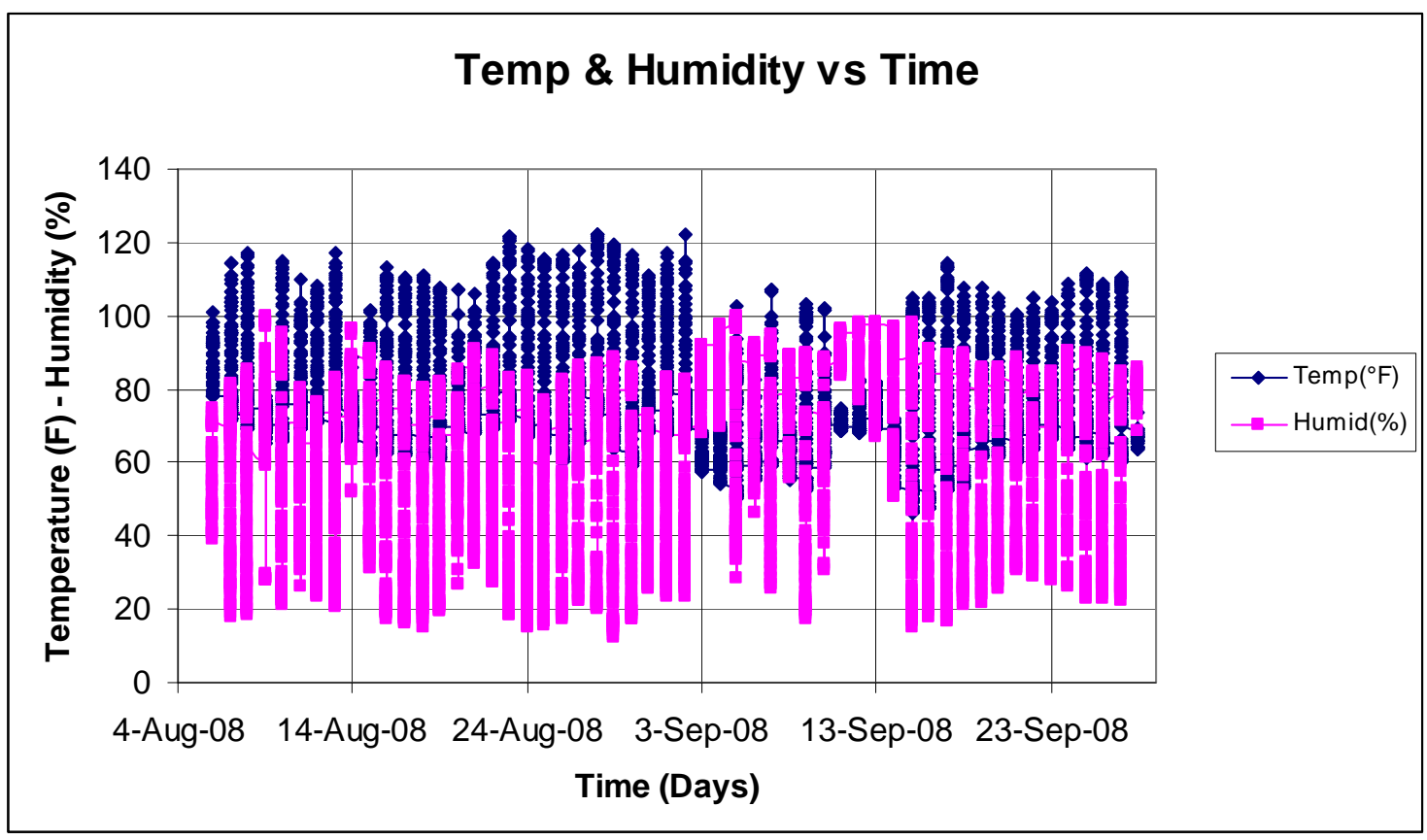

\section{Conclusions and Recommendations}

Following are conclusions about the feasibility of using an evaporator to reduce the water-based metalworking fluid waste stream.

The evaporator can reduce the metalworking fluid waste stream. Testing has shown that the potential is available in the summer and early fall time frame. However, in dealing with water based material there is the potential for freezing. If the unit is to be run into late fall, the system pump must be run full time to prevent freezing.

The evaporator needs to be checked periodically during the day. It cannot be left unattended as currently designed and instrumented. This is especially true when the unit is first charged and the amount of oil that the skimmer can pick up may exceed the waste oil reservoir capacity. Also there is potential for leaks, manifold plugging, and wind gusts catching and moving the rain shield.

If the evaporator leaks and/or spills, there is potential for creating more waste than the evaporator can save. This is especially true if precipitation is involved because of the evaporator location in a confinement area of the barrel lot.

If the evaporator unit was longer, it would have the potential to evaporate more fluid, as proved by adding the extensions and verifying the loss rate rose. 
If the evaporator tank had it own confinement tank, the potential for spill contamination would be greatly reduced. All oil waste containers need to be inside the confinement area. All components need to be under a rain shield. Precipitation could easily fill an uncovered confinement tank .

To operate the unit unattended, additional instrumentation has to be added to the installation and an annunciator panel installed in the waste management area so that personnel could quickly check on the unit.

Potential exists for making the evaporator unit more efficient. There is capacity in the pump to add a third fluid stream though a solar water heater. This would increase the fluid temperature and will affect the evaporation rate. Another suggestion is to add air flow under the rain shield to carry away part of the saturated air. Care must be taken in the unit design to prevent condensed droplets of MWF being released when warm humid air hits the cooler atmosphere. However, since the fluid is water based, no spill hazards are anticipated. Timers could also be added to shut the system down about three hours after sundown and activate the system after sunrise. This would prevent the evaporator from turning into a collector during early morning hours when the evaporator is cooling the fluid and removing air from its surroundings.

Future design must consider the effects of differential expansion on the instrumentation of the evaporator. As long as comparisons are made during the morning the data is valid. Differential expansion increases the measurement error during the day. Since the tank is painted black and the instrumentation is under the rain shield it is affected by the heating of the components. The data logger is within 3 inches of the tank wall and in the afternoon can read almost 30 degrees above ambient temperature. The rain shield, only partially blocked on one side, created its own environment. The location of the unit minimized air flow. This had a negative impact on the evaporation rate but did serve to protect from possible spills due to high wind.

This project contained many unexpected variables. A primary concern is that one spill and the associated contamination could create more waste than the potential benefit of the evaporator. This makes future application doubtful. These risks can be overcome but will increase the unit initial cost and monitoring costs. It would require a substantial amount of evaporation to pay for the expense of the system at an MWF removal rate of $\$ 0.52 /$ gallon, rendering the system non cost effective at this time. 


\section{Appendix}

\section{Observation Sheets}

\begin{tabular}{|c|c|c|c|c|c|c|c|c|c|c|c|c|}
\hline & A & B & C & D & $\mathrm{E}$ & $\mathrm{F}$ & $\mathrm{G}$ & $\mathrm{H}$ & 1 & $J$ & $K$ & L \\
\hline 1 & Date & Time & Temperatura & Humidity & Depth & Gage & Refractomete & $\mathrm{pH}$ & Oil Skim & Add Fluid & Acid & Comment \\
\hline 2 & \multicolumn{3}{|c|}{ Run one Page 1} & & in & Position & \begin{tabular}{|l|} 
Reading \\
\end{tabular} & & Level & (lbs) & Split & \\
\hline 3 & $7 / 7,08$ & $2: 18$ & 106 & 28 & 14.9 & $1716 \mathrm{lb} \mathrm{o}$ & f fluid & & Sample & 1716 & 3.5 & Started-need to make ho \\
\hline 4 & & 3:00 & Sunny & hot & & Full & 2 & 9.22 & A & & & bigger. Started skimmer \\
\hline 5 & & $3: 42$ & 104 & 30 & 14.9 & Holes & enlarged in $\mathrm{me}$ & nanifold $t$ & to $0.032 \mathrm{i}$ & & & oil covered \\
\hline 6 & & \multicolumn{2}{|c|}{ Bright, cloudy } & & \multicolumn{6}{|c|}{ Adjusted flow rate, skimmer working, took sample } & & \\
\hline 7 & & & & & & & & & & & & \\
\hline 8 & $7 / 8,08$ & $7: 16$ & 81 & 66 & 14.5 & $5 / 8$ & & & & & & skimmer started, RS \\
\hline 9 & & & \multicolumn{2}{|l|}{ Partly cloudy } & & & & \multicolumn{3}{|c|}{ Cloudiness increasing } & & \\
\hline 10 & $7,8,08$ & $12: 50$ & 98 & 36 & 14.3 & $5 / 8$ & \multicolumn{6}{|c|}{ Added wear tensions, sphoned to remove oil from end of tank } \\
\hline 11 & & $2: 15$ & 76 & 97 & \multicolumn{4}{|c|}{ Started to rain, unplugged skimmer } & & & & \\
\hline 12 & & & & \multicolumn{5}{|c|}{ Confinement had 2 inches of water this morning } & & & & started skimmer \\
\hline 13 & $7,9,08$ & $7: 10$ & 73 & 28 & 14.3 & \multicolumn{7}{|c|}{ Fuel gage stopped working during the night, will check when confinement is dr: } \\
\hline 14 & & $12: 35$ & 95 & 46 & 14.2 & \multicolumn{5}{|c|}{ Added sheild at right side at of main tank } & & \\
\hline \multicolumn{13}{|l|}{15} \\
\hline 16 & & $1: 30$ & 97 & 42 & 14.15 & \multicolumn{6}{|c|}{ Added shield to right side, moved manifold to right side } & \\
\hline 17 & & & & & \multicolumn{3}{|c|}{ Stopped pump at 3:00 } & & & & & \\
\hline 18 & & $3: 50$ & 104 & 33 & 14.1 & \multirow{2}{*}{\multicolumn{2}{|c|}{ Restarted pump }} & & & & & \\
\hline 19 & & & & & & & & & & & & \\
\hline 20 & $7 / 10,08$ & $7: 20$ & 74 & 88 & 13.95 & \multicolumn{5}{|c|}{ Water condensed on inside of rain shield } & & \\
\hline 21 & & & & & & \multicolumn{5}{|c|}{ Added new splash shield, right side } & & \\
\hline 22 & & $11: 42$ & 93 & 44 & 13.9 & & & & & & & \\
\hline 23 & & $1: 50$ & 100 & 36 & 13.8 & \multicolumn{2}{|c|}{ Lowered Flow } & & & & & \\
\hline 24 & & $2: 24$ & 102 & 33 & \multicolumn{3}{|c|}{ Ran skimmer from $2: 30-3: 30$} & & & & & \\
\hline 25 & $7 / 1,08$ & $7: 14$ & 75 & 84 & 13.7 & \multicolumn{7}{|c|}{ Had rain $@ 5: 30$, for 15 min - some MMF pulling out of hoe $50: 1$} \\
\hline 26 & & & & & & \multicolumn{7}{|c|}{ tank is sitting, no oil slick on top of water in confinement } \\
\hline 27 & & & & & \multicolumn{7}{|c|}{ Retractometer very hard to read in sun, started skimmer } & \\
\hline 28 & & $11: 56$ & 93 & 47 & $13.6+$ & \multicolumn{5}{|c|}{ Starting to rain again - turned off oil skimmer } & & \\
\hline 29 & & $2: 07$ & 90 & 56 & 13.6 & & & & & & & \\
\hline 30 & \multicolumn{12}{|c|}{ A -sample 263.85 , ph 9.22 - ref 2.0 , Hardness 250 ppm nitrate 10 ppm nitrate $0.3-1.0$ ppm Alkalinite 20 drops, acid split-3.5\% } \\
\hline 31 & & $12: 58$ & $95 \mathrm{~F}$ & $46 \mathrm{RH}$ & 13.5 & & & & & & & \\
\hline 32 & & & & & & & & & & & & \\
\hline & & & & & & & & & & & & \\
\hline
\end{tabular}




\begin{tabular}{|c|c|c|c|c|c|c|c|c|c|c|c|c|}
\hline & A & $\mathrm{B}$ & $\mathrm{C}$ & $\mathrm{D}$ & $E$ & $\mathrm{~F}$ & G & $\mathrm{H}$ & 1 & $\mathrm{~J}$ & $\mathrm{~K}$ & L \\
\hline 1 & Date & Time & Temperature & Humidity & Depth & Gage & Refractomete & $\mathrm{pH}$ & Oil Skim & Add Fluid & Acid & Comment \\
\hline 2 & Run $1 \mathrm{P}$ & age 2 & & & in & Position & Reading & & Level & (lbs) & Split & \\
\hline 3 & $7 / 1,08$ & $2: 07$ & 90 & 56 & 13.6 & & & & & & & \\
\hline 4 & $7 M 2,08$ & 9:05am & 82 & 69 & 13.4 & & \multicolumn{2}{|c|}{ Drops on sidewalk } & & & & Cloudy-Drizzel \\
\hline 5 & $7 M 3,08$ & $8: 43$ & 79 & 55 & 13.2 & & \multicolumn{4}{|c|}{ Rained on and off all day Front thru } & & Rain shed covered with wate \\
\hline 6 & & \multicolumn{9}{|c|}{ about 2-3 PM temp and humidity dropped. At 5:45 AM this morning driving east on 95th } & & \\
\hline 7 & & \multicolumn{10}{|c|}{ there was a fog cloud over Blue River and the Complex. Now it is cool and sunny rainshield } & \\
\hline 8 & & \multicolumn{8}{|c|}{ covered. Confinement full of water, no slick open valve to drain. No coolant } & & & \\
\hline 9 & & \multicolumn{7}{|c|}{ leaching out from dirt underneath tank. Let drain. Wiped rainshield. } & & & & \\
\hline 10 & & \multicolumn{8}{|c|}{ Condensate was on the bottom side of rain shield, removed as much as } & & & \\
\hline 11 & & \multicolumn{6}{|c|}{ I could. Turned skimmer on while working on unit. } & & & & & \\
\hline 12 & & 9:05 & 86 & 44 & \multicolumn{3}{|c|}{ Still draining confinement } & & & & & \\
\hline 13 & & $9: 10$ & 86 & & \multicolumn{7}{|c|}{ Finally saw white seepage from under tank and used pigmat } & \\
\hline 14 & & & & 44 & \multicolumn{2}{|c|}{ to gather } & & & & & & \\
\hline 15 & & $9: 12$ & \multicolumn{8}{|c|}{ Stopped draining and closed confinement and valve, pig mat in TPH-2 can } & & \\
\hline 16 & & & \multicolumn{7}{|c|}{ Still some condensate on bottom of rain shield, turned off skimmer } & & & \\
\hline 17 & & $9: 48$ & 88 & 36 & \multicolumn{8}{|c|}{ Went inside and got wegy - now saw white seepage from underneath } \\
\hline 18 & & & \multicolumn{4}{|c|}{ tank. Druged up with pig mat } & & & & & & \\
\hline 19 & $7 M 3,08$ & \multicolumn{11}{|c|}{ Sample weight $249.27 \mathrm{gm}$, ph 9.25 , ref 2.0 , hardness $250-425$, Nitrate $10-20$, Titration $21-22$ drops, acid split } \\
\hline 20 & $7 / 14,08$ & $7: 06$ & 68 & 74 & 13 & \multicolumn{5}{|c|}{\begin{tabular}{|l|l|} 
Tool sample to check concentration in $200 \mathrm{ml}$ \\
\end{tabular}} & & \\
\hline 21 & & $9: 46$ & $93 \mathrm{~F}$ & $33 \%$ & 12.95 & & & & & & & \\
\hline 22 & & $11: 54$ & $100 \mathrm{~F}$ & $23 \%$ & 12.94 & & & & & & & \\
\hline 23 & & $2: 49$ & 104 & $24 \%$ & 12.9 & & & & & & & \\
\hline 24 & $7 M 5,08$ & $6: 07$ & $68 \mathrm{~F}$ & $77 \%$ & 12.8 & & \multicolumn{5}{|c|}{ No morning Dew - did not reach dew point } & \\
\hline 25 & & $7: 09$ & 70 & $73 \%$ & 12.8 & \multicolumn{7}{|c|}{ Added dye supplied with 97022509 to darken fluid added 4 bottles } \\
\hline 26 & & $10: 00$ & $95 \mathrm{~F}$ & $33 \%$ & 12.7 & & \multicolumn{2}{|c|}{ enough for 4 drums } & & & & \\
\hline 27 & & $12: 48$ & $95 \mathrm{~F}$ & $40 \%$ & $12.6+$ & \multicolumn{7}{|c|}{ Dye allowed us to find leak in bottom seam. Use pig putty to } \\
\hline 28 & & & & & & fill gap & & & & & & \\
\hline 29 & & 1:05 & & & & \multicolumn{5}{|c|}{ Installed 2 black painted stainless steel fins } & & \\
\hline 30 & $7 M 6,08$ & $7: 35$ & 72 & $75 \%$ & 12.5 & \multicolumn{3}{|c|}{ Dye makes fluid dark pink } & & & & \\
\hline 31 & & $9: 06$ & 86 & $48 \%$ & 12.5 & & & & & & & \\
\hline 32 & & 9:05 & 93 & 39 & 12.45 & & & & & & & \\
\hline 33 & & & 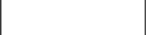 & & & & & & & & & \\
\hline
\end{tabular}




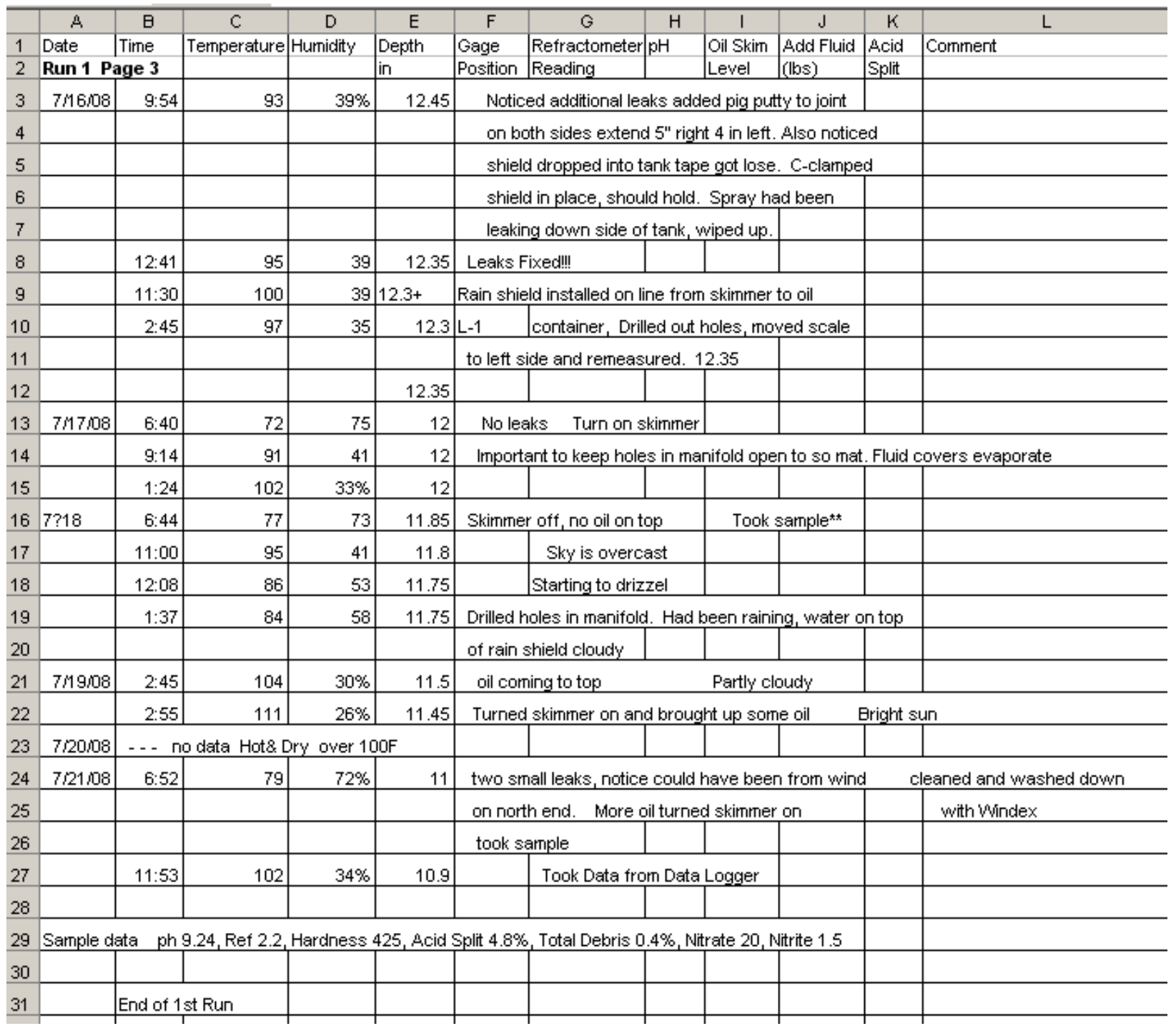




\begin{tabular}{|c|c|c|c|c|c|c|c|c|c|c|c|c|}
\hline & A & B & C & D & $\mathrm{E}$ & $\mathrm{F}$ & G & $\mathrm{H}$ & 1 & J & $\mathrm{K}$ & L \\
\hline 1 & Date & Time & Temperatura & Humidity & Depth & Gage & Refractomete & $\mathrm{pH}$ & Oil Skim & Add Fluid & Acid & Comment \\
\hline 2 & Run 2 P3 & ge 1 & & & in & Position & Reading & & Level & $($ (bs) & Split & \\
\hline 3 & $7 / 24,08$ & $11: 00$ & 97 & $43 \%$ & 10.9 & & & & & & & Begin 2nd Batch \\
\hline 4 & & & & & & & & & & & & u1003785.47 $1331 \mathrm{lbs}$ \\
\hline 5 & & & & & & & & & & & & u1013872.5 for skimmer \\
\hline 6 & & 1240 & 100 & $37 \%$ & 10.9 & & & & & & & \\
\hline 7 & & 1420 & 107 & $33 \%$ & 10.9 & & & & & & & \\
\hline 8 & $7 / 25 / 08$ & $7: 20$ & 75 & $27 \%$ & 10.6 & & & & & & & \\
\hline 9 & & $9: 09$ & 75 & $27 \%$ & 10.6 & & & & & & & Sun coming out \\
\hline 10 & & $12: 20$ & 95 & 53 & 10.5 & & \multicolumn{3}{|c|}{ Side Shield installed } & & & Drain containment \\
\hline 11 & & $1: 15$ & 100 & 43 & 10.5 & & & & & & & Run skimmer .25 hours \\
\hline 12 & & $4: 06$ & 104 & 38 & 10.5 & & & & & & & Pump off for weekend \\
\hline 13 & & & & & & & & & & & & \\
\hline 14 & $7 / 28,08$ & $6: 36$ & 75 & $69 \%$ & 10.5 & & & & & & & Overcast sky, drain water \\
\hline 15 & & & & & & & & & & & & from containment unit \\
\hline 16 & & & & & & & & & & & & plugged in skimmer \\
\hline 17 & & $8: 26$ & $75 \mathrm{~F}$ & $72 \%$ & 10.5 & & & & & & & Unplugged skimmer \\
\hline 18 & & $10: 36$ & 73 & $76 \%$ & 10.5 & & & & & & & Overcast Been raining \\
\hline 19 & & $1: 22$ & 81 & 64 & 10.5 & & & & & & & \\
\hline 20 & & & 77 & 83 & 10.3 & & & & & & & \\
\hline 21 & & $8: 40$ & 82 & $76 \%$ & 10.3 & & & & & & & overcast \\
\hline 22 & & $12: 36$ & 86 & $63 \%$ & 10.3 & & & & & & & overcast sprinkles \\
\hline 23 & $7 / 30,08$ & \multicolumn{8}{|c|}{ Rain all night and most of the day. Unit not accessible in containment area } & & & \\
\hline 24 & & & Pumped dow & n rain wat & ter from re & egion & & & & & & \\
\hline 25 & $7 / 31,08$ & $7: 15$ & 72 & $99 \%$ & 10.3 & & & & & & & \\
\hline 26 & & $12: 53$ & 86 & $97 \%$ & 10.3 & & & \multicolumn{5}{|c|}{ Covered with condensate lower side rain shield } \\
\hline 27 & $8 /, 08$ & $7: 25$ & 75 & $87 \%$ & 10.3 & \multicolumn{7}{|c|}{ Found one extension missing - installed 2 for a total of 5} \\
\hline 28 & & $7: 45$ & 77 & 86 & 10.3 & \multicolumn{7}{|c|}{ Side shields too long adjusted flow too high. Noticed hanging } \\
\hline 29 & & & & & & & from manifold & & & & & \\
\hline 30 & & $12: 46$ & 106 & $38 \%$ & 10.3 & & & & & & & \\
\hline 31 & & & & & & & & & & & & \\
\hline
\end{tabular}




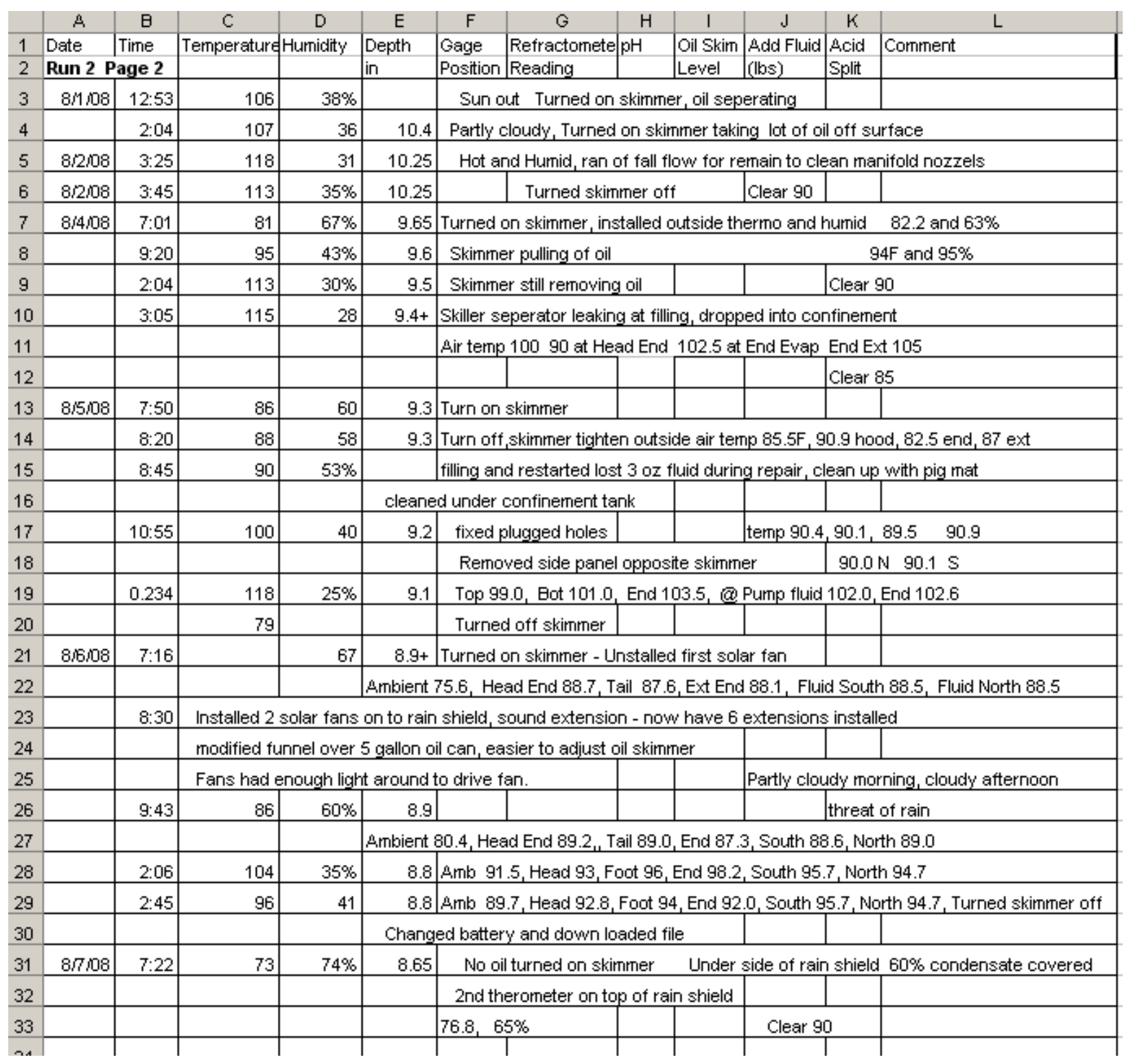









\begin{tabular}{|c|c|c|c|c|c|c|c|c|c|c|c|c|}
\hline & A & $\mathrm{B}$ & $\mathrm{C}$ & $\mathrm{D}$ & $E$ & $\mathrm{~F}$ & G & $\mathrm{H}$ & 1 & $\mathrm{~J}$ & $\mathrm{~K}$ & L \\
\hline 1 & Date & Time & Temperature & Hurnidity & Depth & Gage & Refractomete & $\mathrm{pH}$ & Oil Skim & Add Fluid & Acid & Comment \\
\hline 2 & \multicolumn{2}{|c|}{ Run 2 Page 4} & & & in & Position & Reading & & Level & $(\operatorname{lbs})$ & Split & \\
\hline 3 & $8 M 1,08$ & $10: 36$ & $86 \quad 88.7$ & $50 \quad 42 \%$ & 7.65 & \multicolumn{4}{|c|}{ Partial Cloudy, Power 3.6 to $5.6 \mathrm{KFC}$} & & & Slight oil turned on, $10 \%$ skimmer \\
\hline 4 & & & & \multicolumn{7}{|c|}{ EB 78.3 Amb Head 83.0, Tail 84.3, End 84.4, South 83.1, North 82.7} & & \\
\hline 5 & & & & \multicolumn{7}{|c|}{ KB 75.3, Amb Head 80.7, Tail 81.5, End 81.9, South 80.7, North 80.3} & & \\
\hline 6 & & & & \multicolumn{4}{|c|}{\begin{tabular}{|l|l} 
Power at end 7.65 Sun out & \\
\end{tabular}} & & & & & \\
\hline 7 & & $1: 30$ & $98 \quad 96.4$ & $36 \quad 36 \%$ & 7.6 & \multicolumn{7}{|c|}{ Came out started taking measurements $2.44 \mathrm{kfc}$ for $\mathrm{Eb}$, cloudy } \\
\hline 8 & & & & \multicolumn{9}{|c|}{ EB Amb, 84.7, Head 89.9, Tail 90.0, End 89.3, South 89.3, North 89.4, 10.64 kfc for KB, Sun went back to cloud } \\
\hline 9 & & \multicolumn{2}{|c|}{$60 \%-70 \%$} & \multicolumn{8}{|c|}{ KE A.mb 87.1, Head 87.0, tail 88.7, End 91.9, South 86.9, North 86.4} & \\
\hline 10 & & \multicolumn{2}{|c|}{ cloud cover } & & & & & & & & & \\
\hline \multicolumn{13}{|l|}{11} \\
\hline 12 & & $2: 50$ & $106 \quad 107.4$ & $26 \quad 28$ & 7.55 & \multicolumn{5}{|c|}{ Sun going in and out $8.78-10.16 \mathrm{kfc}$} & & \\
\hline 13 & & \multicolumn{2}{|c|}{ High Cirus } & \multicolumn{7}{|c|}{ Eb Amb 84.5, Head 86.0, Tail 92.3, End 95.9, South 93.0, North 91.5} & & \\
\hline 14 & \multicolumn{3}{|c|}{ wicummulus clouds } & \multicolumn{8}{|c|}{ Kb Amb 81.8, Head 86.5, Tail 87.7, End 88.6, South 85.7, North 80.8} & \\
\hline 15 & & \multicolumn{2}{|c|}{$50 \%-70 \%$} & & & & & & & & & \\
\hline 16 & & & & & Turned o & ff skimme & & & & & & \\
\hline \multicolumn{13}{|l|}{17} \\
\hline 18 & $8 M 2,08$ & $10: 12$ & $86 \%$ & $57 \%$ & 7.55 & \multicolumn{4}{|c|}{ Turned off system and purnped to } & & & \\
\hline \multicolumn{13}{|l|}{19} \\
\hline 20 & & & \multicolumn{2}{|c|}{ Completion of run 2} & & & & & & & & \\
\hline 21 & & & & & & & & & & & & \\
\hline 22 & & & & & & & & & & & & \\
\hline 23 & & & & & & & & & & & & \\
\hline & & & & & & & & & & & & \\
\hline
\end{tabular}




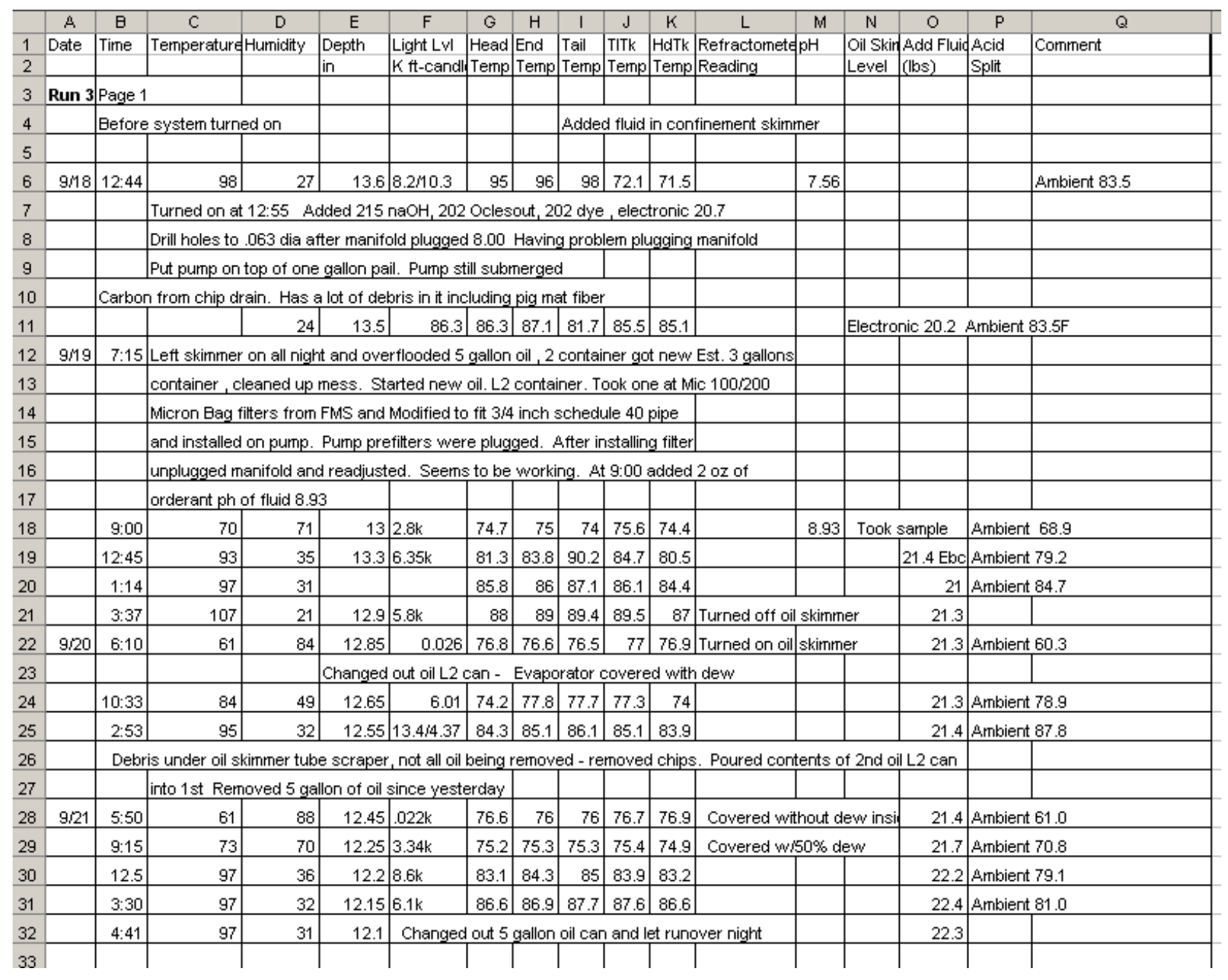




\begin{tabular}{|c|c|c|c|c|c|c|c|c|c|c|c|c|c|c|c|c|c|}
\hline & $A$ & B & $\mathrm{C}$ & D & $E$ & $F$ & $\mathbf{G}$ & $H$ & 1 & $J$ & $\mathrm{~K}$ & L & $M$ & $N$ & 0 & $P$ & Q \\
\hline 1 & Date & Time & Temperature & Humidity & Depth & Light Lul & Head & End & \begin{tabular}{|l|} 
Tail \\
\end{tabular} & TITK & HdTK & Refractomete & $\mathrm{pH}$ & Oil Skin & Add Fluid & Acid & Comment \\
\hline 2 & & & & & in & K ft-candle & Temp & Temp & Temp & Temp & Temp & Reading & & Level & (lbs) & Split & \\
\hline 3 & Run 3 & & page 2 & & & & & & & & & & & & & & \\
\hline 4 & & & & & & & & & & & & & & & & & \\
\hline 5 & $9+22$ & $6: 40$ & 64 & 83 & 11.7 & $.047 \mathrm{k}$ & 77 & 76.6 & 76.3 & 76.7 & 77.2 & & & & & 22 & Ambient 65.4 \\
\hline 6 & & & Decanted oil & $\operatorname{can}$ Mat. Ra & n oil night, & turned in 20 & oil L2 5 & gallon & cans & & & & & & & & \\
\hline 7 & & 10:14 & 81 & 87 & 11.6 & $5.60 \mathrm{k}$ & 76.5 & 77.7 & 78.6 & 77.8 & 75.5 & & & & & 22.3 & Ambient 76.0 \\
\hline 8 & & $2: 27$ & $82 \nleftarrow 102$ & 29 & 11.05 & $7.2 \mathrm{k}$ & 88.7 & 89.7 & 91.6 & 89.3 & 87.3 & & & & & 22.4 & Ambient 82 \\
\hline 9 & & 4:00 & Turned off & skimmer & Top almos & clear of oil & & & & & & & & & & & Ambient \\
\hline 10 & $9+23$ & $6: 55$ & 66 & 81 & 11.55 & $.067 \mathrm{k}$ & 73.9 & 74.6 & 73.8 & 74.2 & 74.2 & \multicolumn{2}{|c|}{ Cover $10 \%$ widew } & & & 22.3 & Ambient 65.9 \\
\hline 11 & & $10: 47$ & 88 & 46 & 11.4 & 4.9 & 77.4 & 80.6 & 79.3 & 79.7 & 76.7 & & & & & 22.7 & Ambient 80.8 \\
\hline 12 & & $2: 10$ & 100 & 31 & 11.35 & 7.3 & 85.4 & 89 & 86.7 & 86.8 & 84.6 & & & & & 22.8 & Ambient 84.9 \\
\hline 13 & & $4: 55$ & 98 & 34 & 11.15 & & & & & & & & & & & 23 & Ambient \\
\hline 14 & $9+24$ & 11:20 & 82 & 63 & 11.1 & 6.9 & 75.5 & 77.9 & 80.5 & 76.4 & 74.6 & \multicolumn{3}{|c|}{ Rained 6:50 AM for 2 hours } & & 22.6 & Ambient 79.6 \\
\hline 15 & & 2:00 & 97 & 36 & 11 & 5.75 & 81.3 & 82.1 & 84.6 & 82.3 & 82 & & & & & & Ambient 82.9 \\
\hline 16 & $9+25$ & $7: 05$ & 61 & 87 & 10.85 & 0.61 & 74 & 73.8 & 73.8 & 74.2 & 74.2 & \multicolumn{4}{|c|}{ a lot of condensate on inside of } & 22.8 & $\begin{array}{l}\text { Ambient } 59.8 \text { very little } \\
\text { outside }\end{array}$ \\
\hline 17 & & & & & & & & & & & & \multicolumn{3}{|c|}{ rain shield - It was raining } & & & \\
\hline 18 & & $9: 00$ & 72 & 74 & 10.75 & 3.51 & 74.2 & 74.5 & 74.8 & 74.6 & 73.3 & \multirow{2}{*}{\multicolumn{4}{|c|}{\begin{tabular}{|l|} 
Removed dew inside - $80 \%$ \\
Lots of condensate on bot of shield \\
\end{tabular}}} & 22.8 & Ambient 68.0 \\
\hline 19 & $9+26$ & $6: 45$ & 63 & 86 & 10.8 & 0.04 & 75.4 & 74.9 & 74.6 & 75.5 & 75.3 & & & & & 23 & 60.1 \\
\hline 20 & & $7: 56$ & 63 & 87 & 10.6 & 0.74 & 74.5 & 74.9 & 74.6 & 75.5 & 74.9 & \multicolumn{4}{|c|}{ Remov'd dew from underside of rain shis } & 22.9 & 64.5 \\
\hline 21 & & 11:00 & 88 & 44 & 10.65 & 5.5 & 77.2 & 78.4 & 80 & 78.5 & 76.6 & & & & & 23.5 & 83 \\
\hline 22 & & $2: 45$ & 104 & 27 & 10.6 & 6 & 87.3 & 89 & 90 & 84.1 & 86.7 & & & & & 23.5 & 87.6 \\
\hline 23 & $9+27$ & $8: 50$ & 66 & 76 & 10.4 & 2.7 & 72.7 & 72.8 & 73.2 & 73.2 & 72.3 & & & & & 23.3 & 67.8 \\
\hline 24 & & $12: 50$ & 100 & 31 & 10.35 & 7.65 & 82.8 & 83 & 85.2 & 84 & 82.5 & & & & & 23.7 & 83.7 \\
\hline 25 & & $4: 16$ & 107 & 22 & 10.3 & 3.97 & 88.7 & 89.5 & 90.5 & 89.6 & 88.6 & & & & & 23.7 & 87.5 \\
\hline 26 & $9+28$ & $8: 44$ & 98 & 32 & 10.05 & 7.8 & 83.2 & 84.2 & 87 & 84.5 & 83.9 & & & & & 24 & 89 \\
\hline 27 & & & & & & & & & & & & & & & & & \\
\hline 28 & & & & & & & & & & & & & & & & & \\
\hline 29 & & & & & & & & & & & & & & & & & \\
\hline 30 & & & & & & & & & & & & & & & & & \\
\hline 31 & & & & & & & & & & & & & & & & & \\
\hline 32 & & $4: 41$ & 97 & 31 & 12.1 & \multicolumn{7}{|c|}{ Changed out 5 gallon oil can and let runover night } & & & 22.3 & & \\
\hline 33 & & & & & & & & & & & & & & & & & \\
\hline 24 & & & & & & & & & & & & & & & & & \\
\hline
\end{tabular}

